Contract No. W-7405-eng-26

METALS AND CERAMICS DIVISION

HTGR Consolidated Fuel Recycle Development Program (189a 0H045)

THORIUM FUEL CYCLE STUDIES - FUEL FABRICATION

PROCESS AND COST ESTIMATION

A. R. O1sen

Date Published - September 1979
This report was prepared as an account of work This report was prepared as an account Nether the sponsored by the Unted United States Department of Ener Energs, subcontractors, or their employees, makes contractors, subeopress or umphed, or assumes any legal any wartany, express or for the accuracy, completeness hiabilty or respof any information, appasatus, product or or usefuiness of any mopresents that its use would no process disclosed, or represents
infringe privately owned nghts

NOTICE This document contains information of a preliminary nature. It is subject to revision or correction and therefore does not represent a final report.

\author{
OAK RIDGE NATIONAL LABORATORY \\ Oak Ridge, Tennessee 37830 \\ operated by \\ UNION CARBIDE CORPORATION \\ for the \\ DEPARTMENT OF ENERGY
}




\section{DISCLAIMER}

This report was prepared as an account of work sponsored by an agency of the United States Government. Neither the United States Government nor any agency Thereof, nor any of their employees, makes any warranty, express or implied, or assumes any legal liability or responsibility for the accuracy, completeness, or usefulness of any information, apparatus, product, or process disclosed, or represents that its use would not infringe privately owned rights. Reference herein to any specific commercial product, process, or service by trade name, trademark, manufacturer, or otherwise does not necessarily constitute or imply its endorsement, recommendation, or favoring by the United States Government or any agency thereof. The views and opinions of authors expressed herein do not necessarily state or reflect those of the United States Government or any agency thereof. 


\section{DISCLAIMER}

Portions of this document may be illegible in electronic image products. Images are produced from the best available original document. 
0

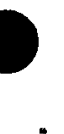




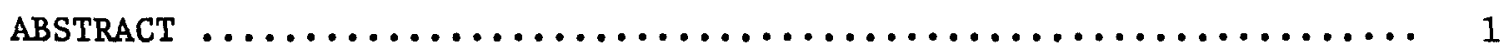

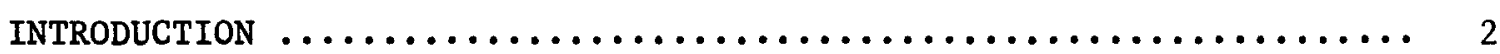

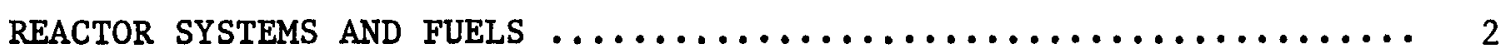

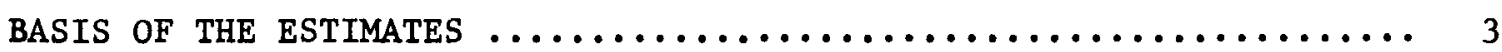

REFERENCE FUEL ELEMENT DESIGNS $\ldots \ldots \ldots \ldots \ldots \ldots \ldots \ldots \ldots \ldots \ldots \ldots \ldots \ldots \ldots \ldots \ldots \ldots \ldots$

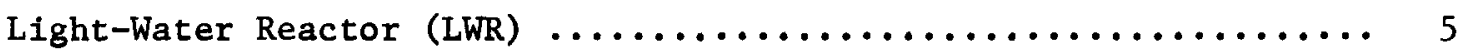

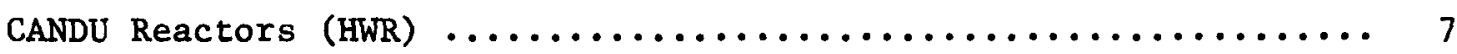

Liquid-Metal Fast Breeder Reactors (LMFBR) $\ldots \ldots \ldots \ldots \ldots \ldots \ldots \ldots$

Gas-Cooled Fast Breeder Reactors (GCFR) ................ 8

High-Temperature Gas-Cooled Reactors (HTGR) $\ldots \ldots \ldots \ldots \ldots \ldots \ldots \ldots$

Light-Water Breeder Reactors (LWBR) $\ldots \ldots \ldots \ldots \ldots \ldots \ldots \ldots \ldots \ldots \ldots$

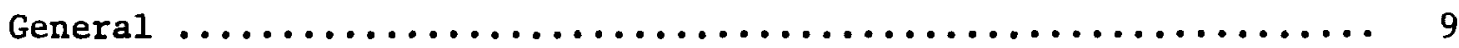

REFERENCE PROCESS DEFINITION $\ldots \ldots \ldots \ldots \ldots \ldots \ldots \ldots \ldots \ldots \ldots \ldots \ldots$

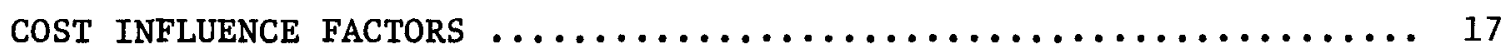

Fuel Materials ............................... 17

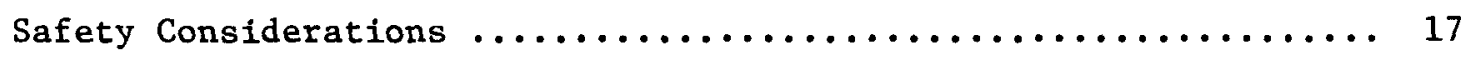

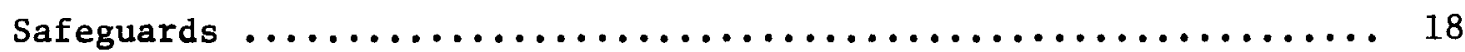

Process Complexity .............................. 19

Fuel Element Design $\ldots \ldots \ldots \ldots \ldots \ldots \ldots \ldots \ldots \ldots \ldots \ldots \ldots \ldots \ldots \ldots$

RELATIVE COST ESTIMATION .......................... 19

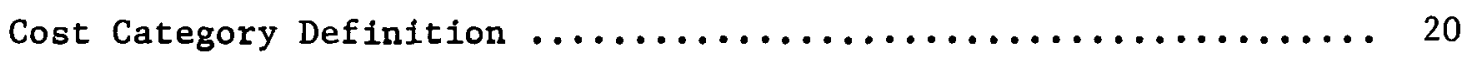

Relative Cost Development ........................ 22

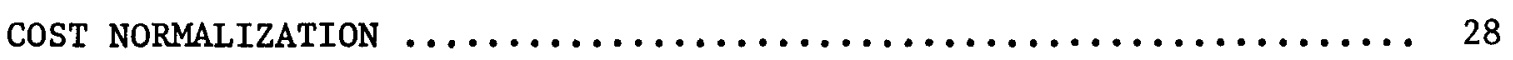

Cost Estimates for Metal-Clad Cylindrical Fuel Rod Types ....... 28

Cost Estimates for Prismatic HTGR Fuel Elements .............. 29

Effects of Plant Capacity on Fabrication Costs ............. 33

UNIT COST ESTIMATION SUMMARY $\ldots \ldots \ldots \ldots \ldots \ldots \ldots \ldots \ldots \ldots \ldots \ldots \ldots \ldots$

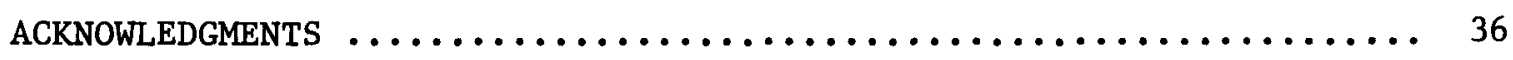

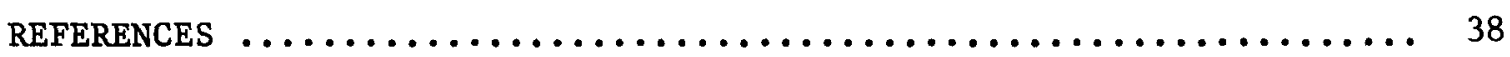


iv

APPENDIX A - DESCRIPTIVE DATA FOR FUEL ELEMENTS USED IN COST ESTIMATES

APPENDIX B - DETAILED RELATIVE COST ESTIMATION - INCREMENTAL

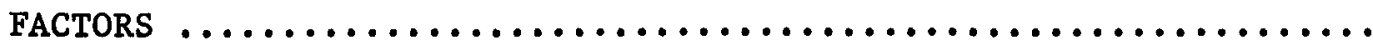




\title{
THORIUM FUEL CYCLE STUDIES - FUEL FABRICATION PROCESS AND COST ESTIMATION
}

\author{
A. R. Olson
}

\begin{abstract}
Early in 1976 a study was made to assess the relative economics and fuel utilization of thorium and uranium fuel cycles in various types of reactors. It was to be completed in approximately two months, so all component parts had to be developed in a short time with a high degree of dependence on existing information. One of the components required for the study was a consistent set of relatively accurate fuel fabrication costs for the various reactor-fuel combinations. Our report documents the rationale used in generating these cost estimates and presents in some detail the basis and methodology employed.

Since three types of thermal flux reactors (LWR, HWR, and HTGR) and two types of fast flux reactors (liquid metal and gas cooled) together with three fuel forms (oxides, carbides, and metal) were included in the study with various combinations of the fissionable metals $U$, Th, and $\mathrm{Pu}$, it was necessary to define a methodology that would permit a rapid relative estimate for each case.

We chose existing cost studies for a Light-Water Reactor with low-enriched uranium fuel and for a High-Temperature GasCooled Reactor with highly enriched uranium and thorium fuel as the reference cases with which we could compare other reactorfuel combinations.

We identified specific fuel element designs and defined process flowsheets. A list of fuel characteristics, process requirements, and regulatory requirements that could affect plant design and operating conditions were compiled. By using these inputs we then estimated each fractional increment in the fabrication cost for each reactor-fuel combination to provide a relative value factor. Finally the relative values were converted to unit coste (dollars per kilogram of heavy metal) by establishing a cost for the reference cases and multiplying this cost by the relative value factor for each derived estimate.

We believe that the relative values are more accurate than the unit costs because of the uncertainties both in the costs for the reference cases and in the regulatory requirements that might be imposed at the time the plants are constructed. However, the unit costs are sufficiently accurate for our overall study purposes, and the set is internally consistent.

Although many of these estimates have been superceded by subsequent studies, the rationale for this original estimate is largely still pertinent. Our subsequent estimates have largely resulted from a modification of this process, with
\end{abstract}


increased consideration of details within each broad cost category. However, we have applied the cost influencing factors associated with fuel materials characteristics, safety considerations, safeguards, process complexity, and fuel element designs in our subsequent studies.

\section{INTRODUCTION}

Early in 1976 ORNL was requested to conduct a short, concentrated study to assess the relative economics and fuel use of thorium and uranium fuel cycles in various types of reactors. ' The study was to be completed in about two months, which necessarily required a high degree of dependence on existing, readily available information.

Our component of this study was to develop a consistent set, of fuel fabrication costs for each reactor-fuel combination that could be used in other components. These data were needed early in the study and consequently were generated in about one month. The objective of our report is to present the rationale used in generating these cost estimates for fuel fabrication and to present in some detail the bases and methodology.

Although many of these estimates have been superceded by subsequent studies the rationale for this original estimate is largely still pertinent. Our subsequent estimates have largely resulted from a modification of this process, with increased consideration of details within each broad cost category. However, we have applied the cost influencing factors assoclated with fuel materials characteristics, safety considerations, safeguards, process complexity, and fuel element designs in our subsequent studies.

\section{REACTOR SYSTEMS AND FUELS}

The initial study was to consider three types of thermal flux reactors: the Light-Water Reactor (LWR), the Canadian Deuterium Uranium Reactor (CANDU), and the High-Temperature Gas-Cooled Reactor (HTGR) together with two types of fast flux breeder reactors: the LiquidMeta1-Cooled Fast Breeder Reactor (LMFBR) and the Gas-Cooled Fast 
Breeder Reactor (GCFR). The study was later extended to include the thermal flux Light-Water Breeder Reactor (LWBR) to the extent that available information would permit.

For each reactor a series of fuel cycles was defined for three fissile components - ${ }^{235} \mathrm{U},{ }^{23}{ }^{3} \mathrm{U}$, and $\mathrm{Pu}$ - and two fertile components ${ }^{238} \mathrm{U}$ and $\mathrm{Th}$. The cycles considered are in Table 1. By eliminating duplications, estimations were reduced to 21 reactor-fuel combinations.

Table 1. Fuel Cycles Considered for Each Reactor Type

\begin{tabular}{|c|c|c|}
\hline Reactor Type & Initial Fuel & Recycle Fuel \\
\hline LWR & $\begin{array}{l}\left({ }^{235} \mathrm{U},{ }^{238} \mathrm{U}\right) \mathrm{O}_{2} \\
\left({ }^{235} \mathrm{U}, \mathrm{Th}\right) \mathrm{O}_{2} \\
(\mathrm{Pu}, \mathrm{Th}) \mathrm{O}_{2}\end{array}$ & 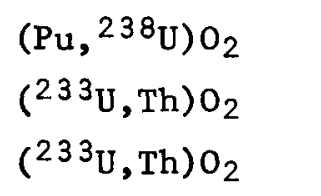 \\
\hline CANDU & $\begin{array}{l}\text { Normal } \mathrm{UO}_{2} \\
\left({ }^{23}{ }^{3} \mathrm{U}, \mathrm{Th}\right) \mathrm{O}_{2} \\
(\mathrm{Pu}, \mathrm{Th}) \mathrm{O}_{2}\end{array}$ & $\begin{array}{l}\left(\mathrm{Pu},{ }^{238} \mathrm{U}\right) \mathrm{O}_{2} \\
\left({ }^{23}{ }^{3} \mathrm{U}, \mathrm{Th}\right) \mathrm{O}_{2} \\
\left({ }^{233} \mathrm{U}, \mathrm{Th}\right) \mathrm{O}_{2}\end{array}$ \\
\hline LMFBR & $\begin{array}{l}\left(\mathrm{Pu},{ }^{238} \mathrm{U}\right) \mathrm{O}_{2} \\
\left(\mathrm{Pu},{ }^{238} \mathrm{U}\right) \mathrm{C} \\
23{ }^{3} \mathrm{U}-\mathrm{Th}(\mathrm{alloy})\end{array}$ & $\begin{array}{l}\left(\mathrm{Pu},{ }^{238} \mathrm{U}\right) \mathrm{O}_{2} \\
(\mathrm{Pu}, 238 \mathrm{U}) \mathrm{C} \\
2{ }^{3} \mathrm{U}-\mathrm{Th} \text { (alloy) }\end{array}$ \\
\hline GCFR & 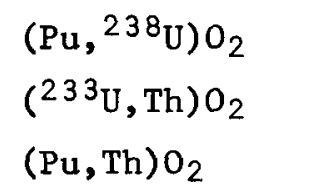 & $\begin{array}{l}\left(\mathrm{Pu},{ }^{238} \mathrm{U}\right) \mathrm{O}_{2} \\
\left({ }^{23}{ }^{3} \mathrm{U}, \mathrm{Th}\right) \mathrm{O}_{2} \\
\left({ }^{23}{ }^{3} \mathrm{U}, \mathrm{Th}\right) \mathrm{O}_{2}\end{array}$ \\
\hline LWBR & $\left({ }^{2}{ }^{3}{ }^{3} \mathrm{U}, \mathrm{Th}\right) \mathrm{O}_{2}$ & $\left({ }^{2}{ }^{3}{ }^{U} \mathrm{U}, \mathrm{Th}\right) \mathrm{O}_{2}$ \\
\hline HTGR & $\begin{array}{l}{ }^{235} \mathrm{UO}_{2}-\mathrm{ThO}_{2} \\
23{ }^{5} \mathrm{UO}_{2}-238 \mathrm{UO}_{2} \\
\mathrm{PuO}_{2}-\mathrm{ThO}_{2}\end{array}$ & $\begin{array}{l}{ }^{23}{ }^{3} \mathrm{UCO}-\mathrm{ThO}_{2} \\
\mathrm{PuO}_{2}-{ }^{238} \mathrm{UO}_{2} \\
{ }^{23}{ }^{3} \mathrm{UCO}-\mathrm{ThO}_{2}\end{array}$ \\
\hline
\end{tabular}

BASIS OF THE ESTIMATES

The objective of our component of the study was to provide a consistent set of fabrication cost factors wherein the relative costs of different reactor-fuel combinations would be as accurate as possible. 
Since other components would assess the value of various combinations, it was necessary to define the cost estimates to suit these other components. To meet this need the relative costs were:

1. normalized to reasonable actual dollar values based on avallable data,

2. reduced to a unit cost basis of dollars per kilogram of heavy metal $(\$ / \mathrm{kg} \mathrm{HM})$ for a nominal production plant capacity, and

3. provided with a scaling factor for variations of cost estimation with industry size.

We derived relative fabrication cost factors from previously reported formal estimation procedures. ${ }^{2,3}$

The preliminary requirements for defining basic data when estimating costs are:

1. establish reference fuel element designs for each reactor-fuel combination,

2. define reference fuel fabrication processes for each fuel, and

3. identify factors that could influence costs.

How these preliminary reguirements were met is discussed in subsequent sections of this report.

To maintain consistency and provide the best possible relative cost factors, we decided to compare the varlous reactor-fuel combinations with common references. Nuclear fuel fabrication is a manufacturing operation, and the basic steps in both fresh and recycle fabrication are essentially the same. However, nuclear fuel for power generating reactors is available in two forms:

1. oxide fuel pellets contained in metal tubes arranged in a mechanical assembly - fuel for commerical Light-Water Reactors [pressurizedwater reactors (PWRs) and boiling-water reactors (BWRs) ${ }^{4}, 5$ ], HeavyWater Reactors (HWRs), Light-Water Breeder Reactors (LWBRs), and fast breeder reactors (either liquid metal or gas cooled) is in this form; and 
2. microspheres coated with layers of ceramlc coatings contained in a graphite assembly - fuel for High-Temperature Gas-Cooled Reactors is of this form.

Thus, two references were selected. All metal clad fuel rod types were compared with the current LWR low-enriched fuel fabrication process with use of the Westinghouse PWR element design. The HTGR elements were compared with $235 \mathrm{UCO}$ fissile particle and $\mathrm{ThO}_{2}$ fertile particle fuel fabrication with use of the General Atomic prismatic fuel element design.

The LWR reference cost factors were derived from an earlier study ${ }^{3}$ and were modified and updated to accommodate current licensing restrictions. The HTGR reference case was derived from an ERDA study ${ }^{6}$ and fit to the LWR cost factors.

\section{REFERENCE FUEL ELEMENT DESIGNS}

As indicated earlier it was necessary to define reference fuel element designs for each reactor-fuel combination. We needed these designs primarlly for our fabrication cost estimate but also used them to estimate the amount and types of nonfuel materials to be handled during reprocessing.

To define these element designs we consulted readily available literature. The various reactor elements are compared briefly in Table 2. Each combination is discussed by reactor type in the following sections, and the design details are presented in the tables of Appendix A.

\section{Light-Water Reactors (LWR)}

Both pressurized-water reactors (PWRs) and boiling-water reactors (BWRs) exist in the current commercial reactor economy. Each type of reactor and each reactor vendor have different fuel element designs. Since Westinghouse has the largest number of operating reactors and a readily available reasonable description of its fuel element design, this design was chosen as the base case for our cost estimate. The information in Appendix A, Table Al, was extracted from a preliminary 
Table 2. Typical Fuel Element Characteristics ${ }^{\alpha}$

\begin{tabular}{|c|c|c|c|c|c|c|c|}
\hline \multirow[b]{3}{*}{ Attribute } & \multicolumn{7}{|c|}{ Reactor Type } \\
\hline & \multirow[b]{2}{*}{ CANDU } & \multirow[b]{2}{*}{ PWR } & \multirow[b]{2}{*}{ BWR } & \multicolumn{2}{|c|}{ LWBR } & \multirow[b]{2}{*}{ LMFBR } & \multirow{2}{*}{$\begin{array}{c}\text { HTGR } \\
\text { (Prismatic) }\end{array}$} \\
\hline & & & & Seed & Blanket & & \\
\hline Cross section shape & Circ & Square & Square & Hex & Ann-Hex & Hex & Hex \\
\hline $\begin{array}{l}\text { Approx dimension, m } \\
\text { (in.) }\end{array}$ & $0.1(4)$ & $0.21(8.4)$ & $0.14(5.4)$ & $0.25(10)$ & $0.43(17)$ & $0.12(4.7)$ & $0.36(14)$ \\
\hline Length, $m($ in.) & $0.495(19.5)$ & $4.06(160)$ & $4.47 \quad(176)$ & $4.27(168)$ & $4.27(168)$ & $4.27(168)$ & $0.76(30)$ \\
\hline $\begin{array}{l}\text { Pins per assembly } \\
\text { (HTGR fuel columns) }\end{array}$ & 37 & 264 & 63 & 619 & 444 & 271 & 132 \\
\hline $\begin{array}{l}\text { Pin diameter, mm } \\
\text { (in.) (HTGR column } \\
\text { diameter) }\end{array}$ & $1.3(0.53)$ & $3.5(0.37)$ & $12(0.49)$ & $6.6(0.26)$ & $14(0.57)$ & $7.9(0.31)$ & $16(0.62)$ \\
\hline $\begin{array}{l}\text { Approx heavy metal } \\
\text { content, } \mathrm{kg}\end{array}$ & 20 & 461 & 190 & 620 & 1760 & 148 & 10 \\
\hline
\end{tabular}

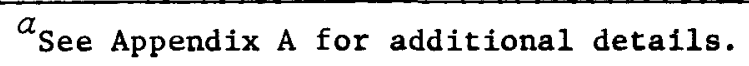


safety analysis report (Sect. 4) for a given reactor design. ${ }^{7}$ The currently preferred design is the 17 by 17 array fuel assembly. Although the pin diameters are different from those used by other PWR manufacturers (Combustion Engineering and Babcock and W1lcox), the competitive nature of the industry would indicate that fabrication costs should be comparable and well within the uncertainties of our estimate. An additional factor that Influenced our choice was the avallability of an earlier detailed cost estimate for a similar design. 3,8

\section{CANDU Reactors (HWR)}

The principal sources of information on the CANDU element design were three papers published in 1970.9-11 Although these references discuss several element designs, we chose one representative of recent reactor fuel. Details of this design are presented in Appendix A, Table A3. Time limitations precluded any consideration of design changes with type of fuel. Thus, a common element design was assumed for all CANDUfuel combinations.

\section{Liquid-Metal Fast Breeder Reactors (LMFBR)}

Selection of a reference fuel element design for the LMFBR was complicated by a variety of considerations. There are two competing commercial power reactor designs in the U.S. This is further complicated by consideration of first generation reactors, the so-called Early Oxide Designs and the later Advanced Oxide Designs. In addition, advanced concepts 1nvolving the carbides, nitride, or possible metal alloy fuels clearly require different designs.

For the oxide fuels most information was readily avallable for the Fast Flux Test Facility (FFTF) 12 reactor driver fuel and the Clinch River Breeder Reactor (CRBR) ${ }^{13,14}$ fuel elements. These were considered in addressing the complexity of the element assembly and fuel parameters, while tabular datal5 for a Westinghouse target plant design were used to generate the fuel rod dimensional data for the commerclal power reactor design for our study. The details are given in Appendix A, Table A4. 
The carbide fuel element design, also thought to be applicable to nitride fuels, was derived from a Combustion Engineering parameter analysis.16 The 9.40-m-OD (0.370-1n.) pin design was selected for the reference in that study. We chose sodium for the fuel-to-cladding thermal bond, although the use of helium-bonded pins may ultimately be identifled as a better design. The design parameters are given in Appendix A, Table A5.

The use of thorium in fast breeder reactors has been under consideration for a long time. However, only a limited amount of performance data is available, and no information was available for a spectflc design for this fuel combination. Since thorlum alloys are not subject to the large swelling rates of urantum alloys 1 7-20 during irradiation exposure, development of this alloy fuel was assumed. A similar conclusion is indicated in a more recent study reported by Electric Power Research Institute (EPRI).21 As a result of the lack of any specific design information, we chose a reference that was essentially the same as for the carbide fuels. The reference parameters are given in Appendix A, Table A6.

\section{Gas-Cooled Fast Breeder Reactor (GCFR)}

Data for the cost estimate reference design for the Gas-Cooled Fast Reactor were derived from a General Atomic report. 22 Only oxide fuels were considered, and the parameters given in Appendix A, Table A7, were used for all GCFR-fuel combinations.

\section{High-Temperature Gas-Cooled Reactors (HTGR)}

There are currently two types of HTGR fuels - the German Pebble Bed Concept and the General Atomic prismatic fuel element. Our study was restricted to the prismatic fuel because design information and other data on which to establish the base case cost estimates for this type of fabrication were readily available. The base case design parameters are presented in Appendix A, Table A8. We recognized that different designs involve variations in the conversion ratio, but the effects of these on fabrication were considered to be within the uncertainties of the estimate; 
thus, the element design for a conversion ratio of 0.66 was the only one considered. This design was assumed for all HTGR fuel combinations.

\section{Light-Water Breeder Reactors (LWBR)}

As indicated in the introduction, the LWBR was added to the study later. Published information on a commercial scale breeder reactor of this type was not available. Consequently, the reference design used in this study was based on the available demonstration plant design data.23-25 Although the current LWBR reactor development program envisages a prebreeder as well as a breeder reactor phase, we considered only the seed and blanket assemblies for the breeder reactor phase. Prebreeder fabrication costs were considered comparable to $\mathrm{LWR}^{-\mathrm{UO}_{2}}$ (low-enrichment) costs. Only a single fuel system was considered in this estimate, as the uncertainties in fuel design for a commercial scale reactor were too high to incorporate in this report.

Genera1

In addition to the specific parameters for each reference design in Appendix A, all available information, including drawings, tolerance, and quality control features for each assembly, were considered in our cost estimation.

\section{REFERENCE PROCESS DEFINITION}

A second prerequisite for making the cost estimates was to establish reference process flowsheets for each of the fuels and fuel elements. We used these flowsheets to assess the relative requirements in equipment, manpower, and time.

For most of the fuels considered the fuel element fabrication process starts with the receipt of fissile and fertile oxide powders. The conversion processes are included in the reprocessing cost estimates. The powder preparation step includes both conditioning and blending, which must precede pellet fabrication, grinding (if necessary), inspection, and a final conditioning to remove dust and moisture. The third stage 
of rod fabrication includes hardware preparation and actual insertion of the fuel and other internal components into the cladding, final closure and complete quality control testing. The final step of element assembly involves hardware preparation, assembly, and extensive quality control testing to assure element integrity and performance in the reactor.

Each process step, particularly powder preparation and pellet fabrication, generates a significant amount of scrap material. To produce a unit of acceptable product industrial experience has shown that between 1.1 and 1.2 units must be processed in the early fuel fabrication. This scrap is far too valuable to discard, so a scrap recycle system is economically justified. In addition, after recovering the valuable fissile materials the reusable chemicals should be reclaimed and all other wastes treated and prepared for final disposition. Current federal regulations have placed tight restrictions on 1iquid, gaseous, and solid wastes. Thus, the auxiliary processes of scrap recovery and waste treatment have become important economic considerations in fuel manufacturing. Though we did not develop reference flowsheets for these auxiliary systems, we considered the degree of complexity and extent of these systems in our actual estimation.

The actual processing must be tailored for each reactor type and each fissile and fertile component. However, the main steps can be generically identified on the basis of compounds and compositions to provide an adequate reference, which can provide a basis for relative cost estimation. To this end we prepared simplified process flowsheets, which are described below.

Both the generic nature of these flowsheets and the similarity between fresh and recycle fuel manufacturing can be seen in Fig. 1. This flow diagram addresses the typical steps in processing oxide powders to fuel elements and can be used for the LWR, CANDU, or LWBR reactors, which contain fuel pellets in Zircaloy tubes for the individual fuel rods. The process steps are essentially unchanged with fuel composition variables although batch and lot sizes may vary significantly because of considerations such as prevention of criticality. Thus, low-enriched $\mathrm{UO}_{2}$ for the LWR fresh fuel would start with $\mathrm{UO}_{2}$ powder of the appropriate 
enrichment in large batches and lot sizes to minimize process adjustments in the subsequent pelletizing processes. On the other hand, for recycle fabrication using plutonium as the fissile component, the $\mathrm{PuO}_{2}$ batch sizes would have to be restricted, and separate conditioning of the $\mathrm{UO}_{2}$ and $\mathrm{PuO}_{2}$ before batch blending would probably be required. The mixed oxide, with about $3 \% \mathrm{PuO}_{2}$, would permit the accumulation of larger lots than would be permissible with the fast reactor fuels in which the $\mathrm{PuO}_{2}$ content might be as high as $30 \%$.

Figure 2, while very similar to $\mathrm{Fig}$. 1, introduces some of the complications associated with variable fuel rod contents, specifically the axial blanket $\mathrm{UO}_{2}$ in the fast breeder reactor. This flowsheet is applicable to oxide fuels for both the LMFBR and GCFR.

The reference process flowsheet for carbide fuels in Fig. 3 was based on the carbothermic reduction of oxide powders. Although this process has not been proven on a commercial scale, we felt that its economic advantages would result in its being chosen for fabrication of advanced fuels. Because of the lack of commercial experience the process flowsheets and the resulting estimates have a somewhat higher degree of uncertainty than those for oxide fuels.

The uranium-thorium alloy process in Fig. 4 has an even higher degree of uncertainty than the carbide system. Each of the process steps has been proven on a laboratory 8 cale, 26 and a significant amount of $235 \mathrm{U}-\mathrm{Th}$ alloy fuel has been irradiated in core II of the Sodium Reactor Experiment. 27 However, commercial scale processing, particularly with $233 \mathrm{U}$, has not been demonstrated. This process flowsheet represents only one of several alternatives.

The HTGR fuel fabrication process in Fig. 5 is based on our development of HTGR fuels and our recent work in the development of processes and equipment to be used in a proposed High-Temperature Gas-Cooled Reactor Recycle Demonstration Facility (HRDF). 28 As with other fuels the fresh and recycle fuel manufacturing processes are very similar. 
ORNL-DWG 76-5070
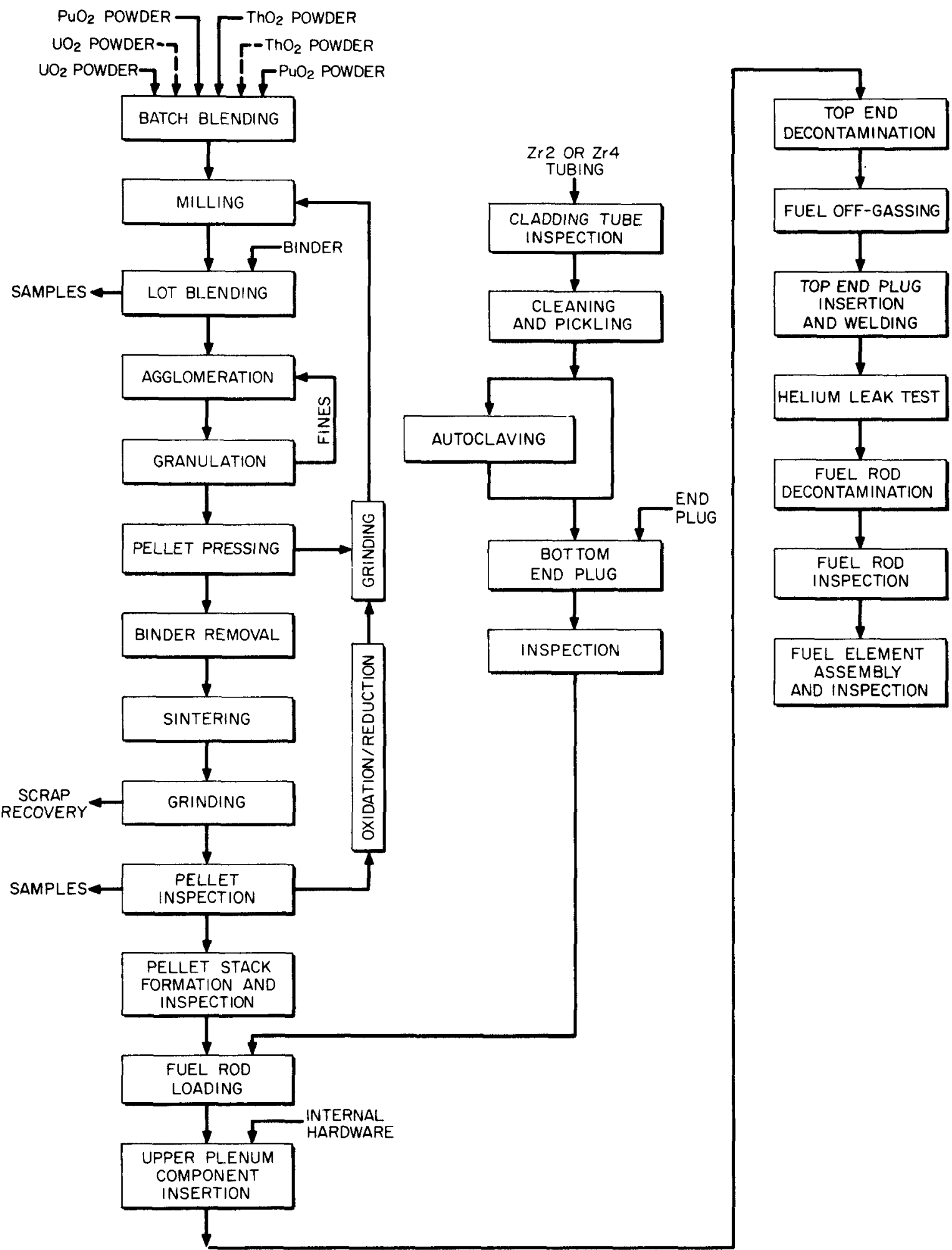

Fig. 1. Oxide Fuel Element Fabrication. 


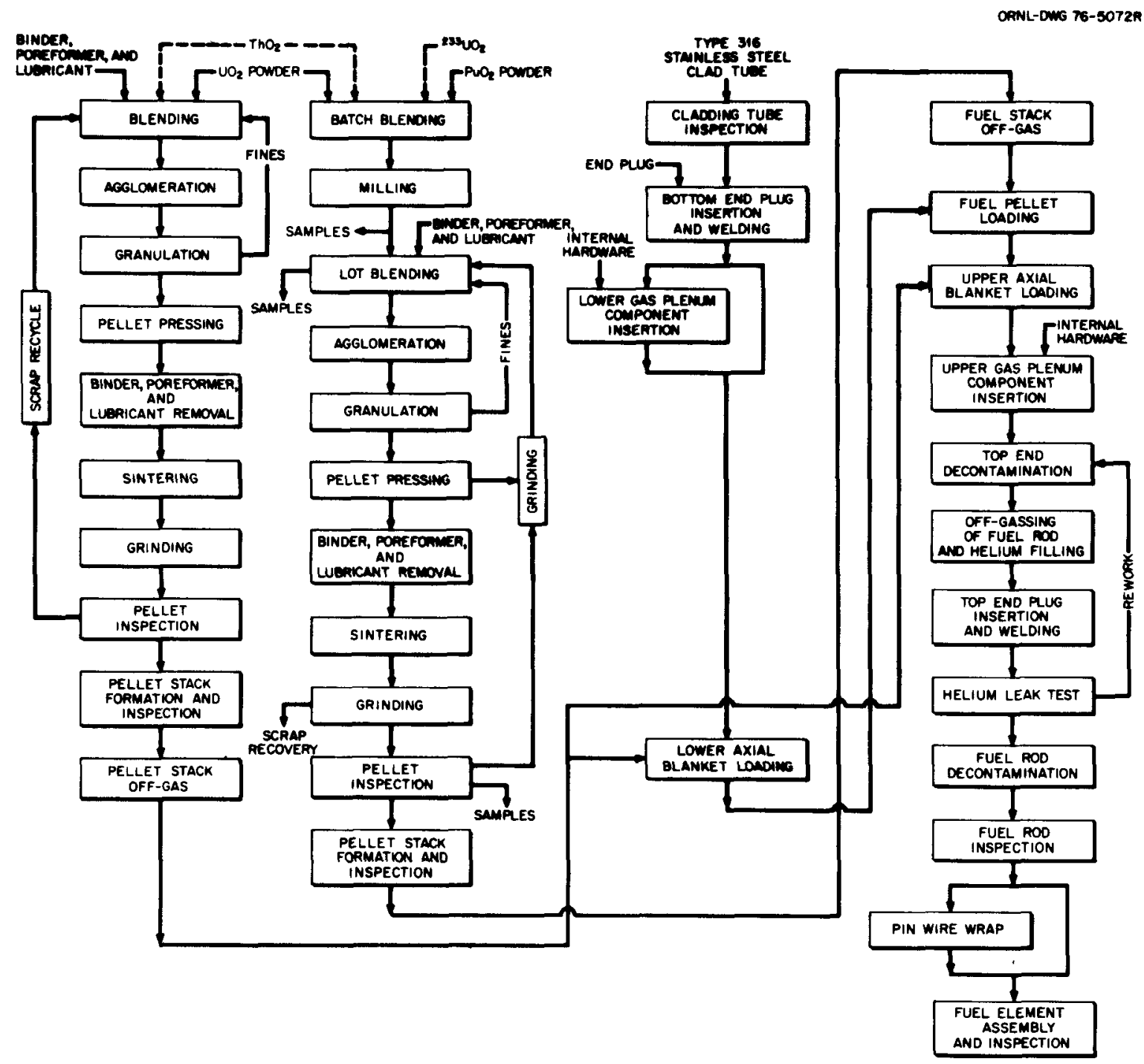

Fig. 2. FBR Oxide Fuel Element Fabrication. 


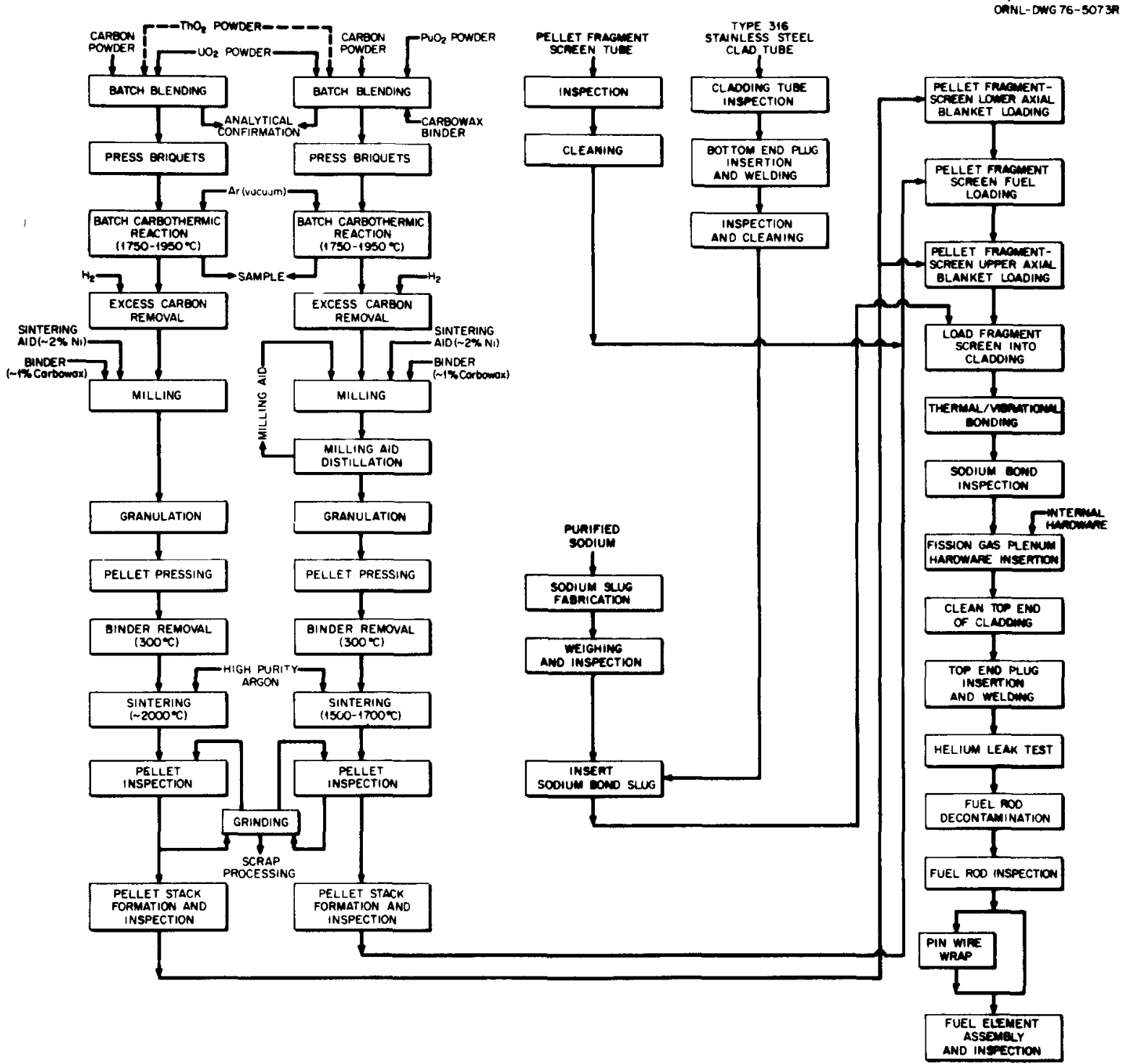

Fig. 3. FBR U-Pu Carbide Fuel Element Fabrication. 


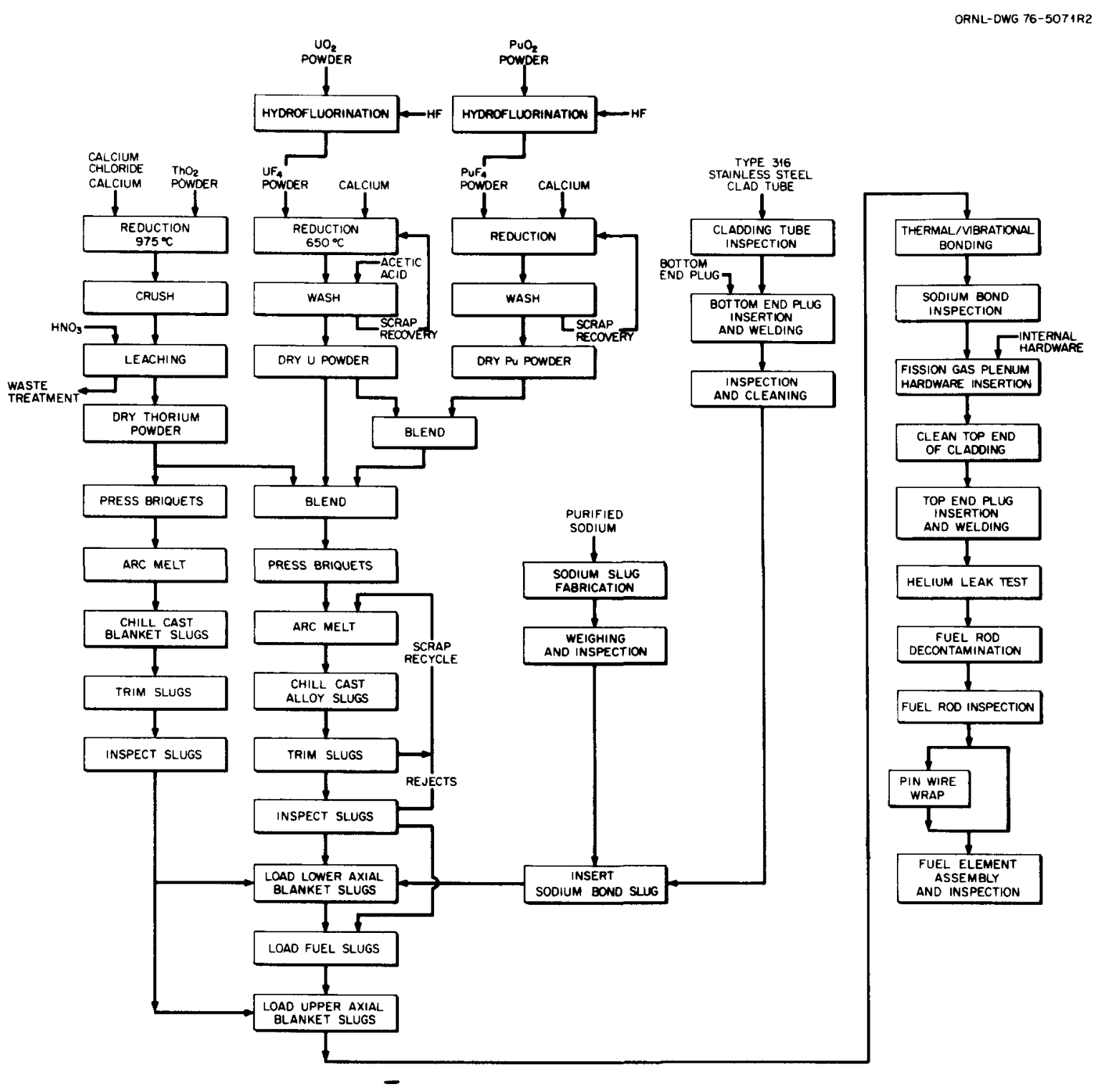

Fig. 4. FBR ${ }^{23}$ U-Th Metal Fuel Element Fabrication. 


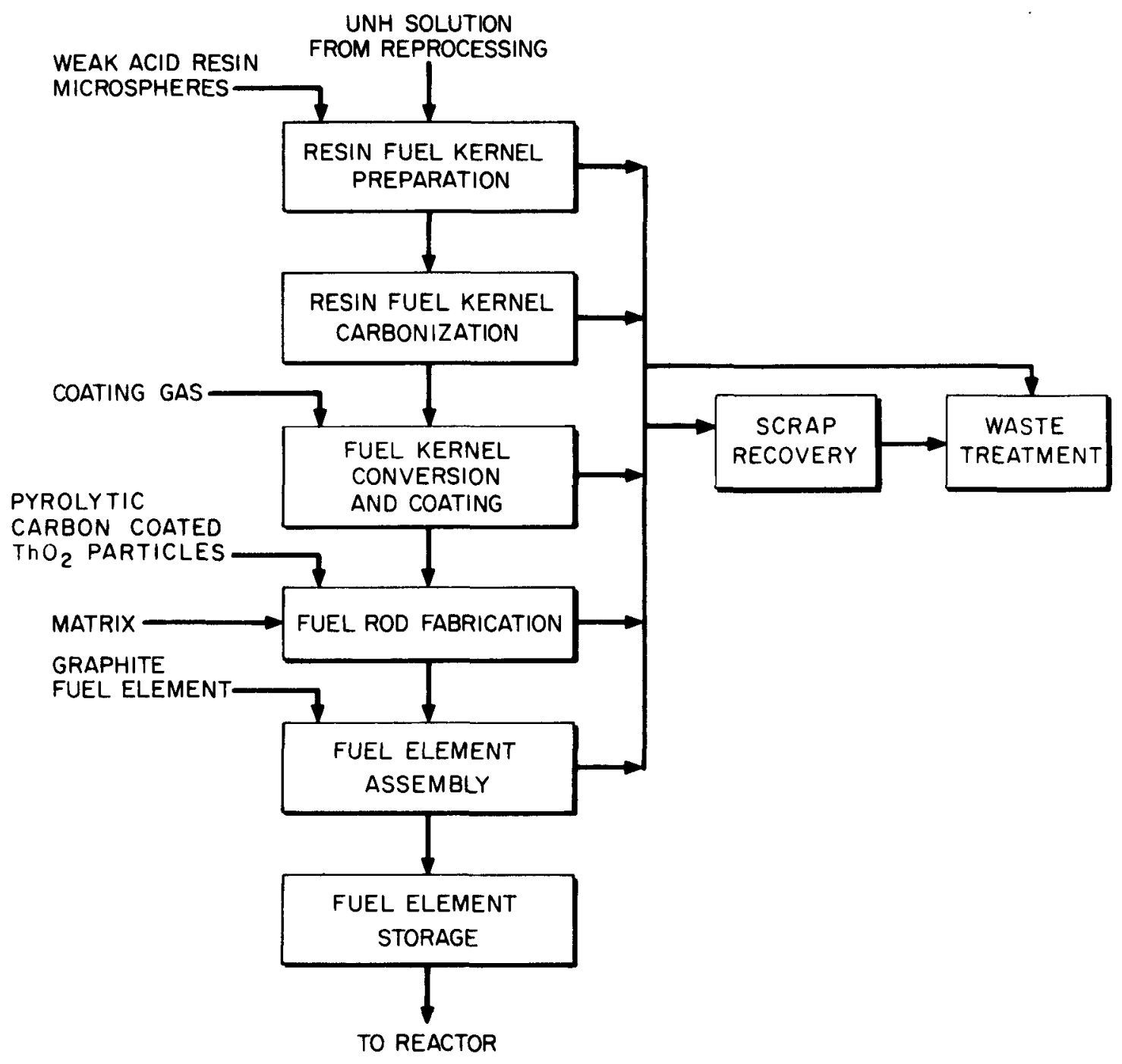

Fig. 5. Process for HTGR Recycle Fabrication. 


\section{COST INFLUENCE FACTORS}

The fabrication costs for each reactor-fuel combination are subject to a number of imposed influences. For example, the product attributes are defined by both reactor designers and safety analysis considerations, while the fabrication plant design and operating procedures depend highly on both material characteristics and licensing regulations. In preparing a relative cost estimate we must consider all these factors. However, five major considerations predominate: fuel materials, safety, safeguards, process complexity, and fuel element design. Except for fuel materials these considerations are all interdependent; each is influenced by all of the others and in turn influences them.

Fuel Materials is the most important consideration. Fuel materials are the basic constituents in the fissile and fertile components.

Each fissile component has a set of characteristics that determine safety and safeguard considerations. The relatively low specific activity and biological hazards of ${ }^{235} \mathrm{U}$ permit the design and operation of a plant that uses contact (hands-on) fabrication. On the other hand, biological hazards of plutonium require that all operations be performed in contained equipment to prevent operator exposure. In addition, depending on the plutonium isotopic distribution, shielding against penetrating radiation may be required. The chemical characteristics increase both process complexity and safeguards considerations. Similar to plutonium as a biological hazard from ingestion, $29233 \mathrm{U}$ requires significant shielding as well as containment of most of its processes because of the high energy of the gamma rays from a decay product of contained ${ }^{232} \mathrm{U}$. A relative comparison of radiation dose levels for the three types of fissile components is given in Table 3.

The fertile components ${ }^{238} \mathrm{U}$ and thorium have a less significant effect on cost because of their lower inherent biological hazard but do influence the process complexity because of different chemical characteristics.

Safety Considerations, as discussed above, is predominantly influenced by the inherent characteristics of the fissile component. Included in these characteristics is the potential for accumulating a 
Table 3. Radiation Dose Levels for Various Fissile Components

\begin{tabular}{|c|c|c|}
\hline \multirow[b]{2}{*}{ Fissile Component } & \multicolumn{2}{|c|}{$\begin{array}{c}\text { Radiation Dose Rate, } \\
\text { millirem/h }\end{array}$} \\
\hline & Gamma & Neutron \\
\hline $\mathrm{UO}_{2}\left(3-4\right.$ wt $\left.\%{ }^{235} \mathrm{U}\right)$ & $<0.01$ & 20 \\
\hline $\mathrm{PuO}_{2}(100 \mathrm{~d} \text { after separation })^{b}$ & 5 & 1 \\
\hline${ }^{233} \mathrm{U}(100 \mathrm{~d} \text { after separation })^{b}$ & 750 & 0.1 \\
\hline
\end{tabular}

$a_{\text {Measured at }} 0.5 \mathrm{~m}$ from steel container $(0.5 \mathrm{~mm}$ wa11) loaded with $0.5 \mathrm{~kg} \mathrm{HM}$.

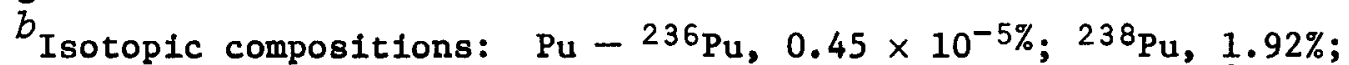
$23{ }^{9} \mathrm{Pu}, 63.3 \%$; $240 \mathrm{Pu}, 19.2 \%$; $241 \mathrm{Pu}, 11.68 \%$; and $242 \mathrm{Pu}, 3.88 \%$. ${ }^{23} 3 \mathrm{U}-$ ${ }^{232} \mathrm{U}, 0.05 \%$; ${ }^{23}{ }^{3} \mathrm{U}, 92.1 \%$; ${ }^{234} \mathrm{U}, 7.35 \%$; and $235 \mathrm{U}, 0.57 \%$.

critical mass. Although the precise quantities required for a critical mass depend upon a number of conditions, significantly less material is required for either $\mathrm{Pu}$ or ${ }^{233} \mathrm{U}$ than for ${ }^{235} \mathrm{U}$. Thus, cost can significantly increase from fabrication equipment component size and spacing requirements together with batch and lot size limitations.

Safeguards is predominantly a social and political consideration. However, some of the requirements are met naturally by good business practice for both economic and safety reasons. The value of the fissile material is such that a loss represents a significant economic penalty, and the orderly movement and monitoring of material through the fabrication process is required to assure product acceptability and reduce rejects with their obvious effects on profits.

Other safeguard features require that plant design and operational procedures detect and prevent unauthorized removal of the material by either covert or overt actions. The extent of these features will vary with the fissile component and enrichment. Since plutonium is readily separable by chemical processes from other fuel components and a relatively small amount is needed for an explosive device, it will require the most stringent protection. Highly enriched uranium containing either ${ }^{235} \mathrm{U}$ or ${ }^{233} \mathrm{U}$ must also be provided with this high degree of protection. 
Process Complexity can be derived from analysis of the reference process flowsheets described earlier. However, additional items that influence fabrication cost were considered. Product quality assurance activities vary with the process and are increased as batch and lot sizes decrease or design tolerances tighten. Typically, quality assurance can account for up to $30 \%$ of the operating cost in current LWR fabrication. Equipment maintenance is an extremely important part of the cost in that space, and equipment to accommodate these activities must be incorporated in the plant design, operating personnel exposures must be considered, and a judgment must be made on the need for installed spares to assure continued plant productivity. Two additional elements, scrap recovery and waste treatment, are strongly influenced by both the fissile and fertile components. The chemical characteristics of both plutonium and thorium require the use of halldes in the scrap recovery dissolution process, which increases the system costs and complicates the waste treatment and recycle of liquids. The decay products of the ${ }^{232} \mathrm{U}$ isotope in the ${ }^{233} \mathrm{U}$ fissile component increase the complexity of off-gas treatment systems. Both plutonium and $233 \mathrm{U}$ in solid waste can change the storage category.

Fuel Element Design has been addressed earlier in defining the reference designs. The dominant factors influencing cost are fuel diameter, fuel density, fabrication tolerances, contaminant specifications, hardware complexity, and enrichment variables.

\section{RELATIVE COST ESTIMATION}

To obtain a consistent set of costs for all the reactor-fuel combinations we wanted to establish a systematic cost component breakdown. Typically, costs cover capital, hardware, and operation. These define the fabrication costs exclusive of any fissile component costs. In the past where detailed element designs, plant conceptual designs, and specific process definitions have been available, cost has been estimated with sophisticated computer codes. ${ }^{2,3}$ 


\section{Cost Category Definition}

The large variety of fuel materials and fuel element designs in our study precluded the use of computerized estimation. However, the LWR (PWR) case $^{3}$ from FABC $\varnothing S T 9$ formed the basis for the reference for metal clad cylindrical fuel rod types and provided the appropriate distribution of cost elements under the categories of capital, hardware, and operation, as shown in Table 4.

This table is similar to the breakdown given in the reference document ${ }^{3}$ but varies in two important ways. First, a fourth category covering fuel element design factors has been added. It is included to accommodate both the effects of fuel rod diameter changes for the metal clad tubular rod fuel elements and the density changes associated with fuel compound varlations. These factors are used to adjust the cost estimates for different design and fuel compounds when they are converted to a unit basis. The adjustment is usually made on the sum because all categorles are affected by changes in fuel mass per unit length of rod. The second modification is the addition of scrap recovery and waste treatment. These elements were added because they are currently required or anticipated for licensing ${ }^{30}$ U.S. commercial fabrication plants. They must be considered in both capital and operating cost categories.

The numerical values for each category were derived from the earlier study $^{3}$ after making adjustments to incorporate the new features. These adjustments were based on the anticipated effect of new regulations pertaining to material accountability, environmental protection, scrap recovery, and waste treatment. We assumed an increase of $50 \%$ for capital and $40 \%$ for operation. Both were based on an assumed recycle fraction of $30 \%$ for the fuel material, which includes quality control samples and preparation of all waste for solid disposal.

The cost element fractions ${ }^{5}$ were also derived from the previous study $^{3}$ of a contact operation plant. The fractional breakdown of the operating cost was recalculated after the addition of the manpower units for scrap recovery and waste treatment. For the capital costs two sets of elemental fractions are included. The contact-operation breakdown of 0.66 for equipment and 0.33 for building was derived from the earlier 
Table 4. Cost Estimation Component Factors ${ }^{a}$

\begin{tabular}{|c|c|c|c|c|}
\hline & \multirow[b]{2}{*}{ Categories } & \multirow{2}{*}{$\begin{array}{l}\text { Percent of Total for } \\
\text { Categorles for Current } \\
\text { PWR Elements }\end{array}$} & \multicolumn{2}{|c|}{ Element Fraction } \\
\hline & & & Contact & Other \\
\hline \multirow[t]{4}{*}{ A. } & Capital costs & 33 & & \\
\hline & 1. Equipment & & 0.66 & 0.5 \\
\hline & 2. Building & & 0.33 & $\underline{0.5}$ \\
\hline & & & 1.00 & 1.0 \\
\hline
\end{tabular}

B. Fuel element hardware

38

1. Cladding with end caps 0.36

2. Fuel rod internals Neg

3. Assembly hardware $\underline{0.64}$

C. Operation $b$

1. Cladding preparation $\quad 0.19$

2. Fuel preparation $\quad 0.48$

3. Rod loading $\quad 0.02$

4. Element assembly, inspec- 0.04

5. Scrap recovery $b$. 14

6. Waste treatment $b \quad \underline{0.14}$

Total 100

D. Fuel element design factors

(metal clad)

1. Fuel density [case fuel density $\left(\mathrm{g} / \mathrm{cm}^{3}\right) \div$ $10.4=X]$

2. Fuel diameter [diam (in.) $\div 0.315=Y]$

$100(X)(Y)$

$a_{\text {Factors derived from FABC } \emptyset \mathrm{ST}} 9$ PWR case: A. L. Lotts, T. N. Washburn, and F. J. Homan, FABCØST 9, A Computer Code for Estimating Fabrication Costs for Rod-Bundle Fuel Elements, ORNL-4287 (August 1968).

$b_{\text {Factors adjusted to include scrap recovery and waste treatment that }}$ were added for current licensing considerations. 
study. However, In view of the additional costs involved in the more complicated building structure, the additional services, and the additional space requirements for maintenance functions needed for other types of operations, we split the capital costs for all other types of operation equally between the equipment and building. Multiplying the category fraction times the cost element fraction defines explicity the cost contribution for that element for the reference case. This is the reference element increment. Each increment represents a specific fraction of the fuel fabrication costs for the reference reactor-fuel combination.

Relative Cost Development

After establishing the element fractional estimates for the reference cycles, we estimated the cost for alternative reactor fuel by assigning an incremental multiplier to each fractional element for a given reactorfuel combination. For the capital and operating categories no single incremental modifier can be considered separately. One must judge between additional capital costs to provide mechanized process equipment, spares, maintenance space and accessories, etc., and lower operating costs by reducing manpower requirements, plant avallability, etc.

Since most of the fuels considered represent a significant safety hazard to operating personnel and more restrictive regulations on permissible operating personnel radiation exposures are antlcipated, we assumed a high degree of process automation for all plants. These considerations were augmented by the economics of material flow monitoring and accountability, the generally more uniform product characteristics of mechanized operation, and the large amount of quality control data and records that must be collected and collated to satisfy both the customer and the Nuclear Regulatory Commission auditors that the product element is suitable for use in a commercial power reactor. Finally, the higher degree of automation is more readily adapted to provide process information that may be needed to satisfy safeguards requirements and to reduce the man-material interfaces that must be monitored to prevent overt removal of material. 
Changing federal regulations, the cost of construction, the availability of skilled manpower, and other business considerations can alter the balance between the capital and operating categories for a given commercial venture. Therefore, each incremental multiplier, element fraction, and category fraction is considered less reliable than the integral of all these components for each reactor-fuel combination estimate.

In selecting the incremental multipliers we considered all the reference fuel element designs and reference process flowsheets. The primary influence on the value of the multiplier was, as indicated earlier, the fissile component of the fuel. The tables in Appendix B include the spectfic incremental multipliers for each reactor-fuel combination.

The equation for calculating the individual portions of each reactorfuel combination cost factor is

$\mathrm{CF}$ (Category Fraction) $\times \mathrm{EF}$ (Element Fraction) $\times$ IM (Incremental
Multiplier) = Estimated Incremental Relative Cost Factor

The summation of the relative element increments yields the total relative cost factor of the given combination.

The final adjustment of the reactor-fuel combination relative cost factors involved corrections for fuel density and fuel diameter for each of the tubular rod assemblies. The needed data derived from the element descriptions of Appendix $A$ and the factors derived are presented in Appendix B.

Table 5 is an example of the development of relative cost factors for LWR (PWR) fuel elements where dimensional and density adjustments are not required. In this example two types of commercial fabrication plants were considered for the Mixed oxide (MOX) $\mathrm{PuO}_{2}-{ }^{238} \mathrm{UO}_{2}$ recycle fuel. For both the glove-box and fully remote operations the fuel assembly hardware cost elements neither 1ncrease nor decrease when compared with the current LWR $(235 \mathrm{U}-235 \mathrm{U}) \mathrm{O}_{2}$ fuel; so the incremental multipliers are 1 . This unit multiplier does not apply to most of the elements of the capital and operating cost categories. Consideration 
Table 5. Example of Relative Cost Estimation

\begin{tabular}{|c|c|c|c|c|c|c|c|}
\hline & & \multirow{2}{*}{$\begin{array}{l}\text { Category } \\
\text { Fraction }\end{array}$} & \multirow{2}{*}{$\begin{array}{l}\text { Element } \\
\text { Fraction }\end{array}$} & \multicolumn{2}{|c|}{$\begin{array}{l}\text { LWR-MOX } \\
\text { Glove Box }\end{array}$} & \multicolumn{2}{|c|}{$\begin{array}{l}\text { LWR-MOX } \\
\text { Remote }\end{array}$} \\
\hline & & & & $\mathrm{IM}^{a}$ & Estimate & $\mathrm{IM}^{a}$ & Estimate \\
\hline \multirow[t]{4}{*}{ I. } & Capital costs & 0.33 & & & & & \\
\hline & Equipment & & 0.5 & 1.5 & 0.25 & 3 & 0.50 \\
\hline & Building & & 0.5 & 3.0 & $\underline{0.50}$ & 6 & $\underline{0.99}$ \\
\hline & Estimated factor & & & & 0.75 & & 1.49 \\
\hline \multirow[t]{5}{*}{ II. } & Hardware costs & 0.38 & & & & & \\
\hline & Cladding plus end plugs & & 0.36 & 1 & 0.14 & 1 & 0.14 \\
\hline & Rod internals & & & 1 & $\mathrm{Neg}$ & 1 & Neg \\
\hline & Assembly hardware & & 0.64 & 1 & $\underline{0.24}$ & 1 & 0.24 \\
\hline & Estimated factor & & & & 0.38 & & 0.38 \\
\hline \multirow[t]{9}{*}{ III. } & Operating costs & 0.29 & & & & & \\
\hline & Cladding preparation & & 0.19 & 1 & 0.06 & 1 & 0.06 \\
\hline & Fuel preparation & & 0.48 & 5 & 0.70 & 5 & 0.70 \\
\hline & Rod loading & & 0.02 & 2 & 0.01 & 2 & 0.01 \\
\hline & $\begin{array}{l}\text { Element assembly inspection } \\
\text { and packaging }\end{array}$ & & 0.04 & 2 & 0.02 & 10 & 0.12 \\
\hline & Scrap recovery & & 0.14 & 4 & 0.16 & 4 & 0.16 \\
\hline & Waste treatment & & 0.14 & 10 & 0.40 & 10 & 0.40 \\
\hline & Estimated factor & & & & 1.35 & & 1.45 \\
\hline & $\begin{array}{l}\text { Total estimated rela- } \\
\text { tive cost factor }\end{array}$ & & & & 2.48 & & 3.32 \\
\hline
\end{tabular}

\footnotetext{
$a_{\text {Increment multiplier. }}$
} 
must be given to other factors as indicated in Table 6. For example, the equipment cost for glove-box operation is 1.5 times as expensive as that for contact operations. This $1 \mathrm{~s}$ a result of space and access restrictions, sealed service connections through the containment wall, and localized shielding for regions of high plutonium material accumulation. The fully remote equipment is 3 times as expensive as contact operations. Th1s increased cost provides for remote component replaceability and other malntenance as well as the additional equipment to replace some operations (such as pressure adjustment controls for the pellet press), which could be done by the operators in the glove-box operations. Batch and lot size restrictions for both glove-box and remote operations increase the number of process lines in the system to provide equivalent annual capacity. This is needed only in the early stages of fabrication when plutonium is concentrated. Bullding cost incremental multipliers are influenced by similar considerations, as shown in Table 6 . However, the additional ventllation requirements; space needed for maintenance operations; isolation of plutonium scrap; waste treatment of chemical processing liquids, which may contain corrosive chemfcals; and safeguards considerations make these incremental multipliers larger. A similar rationale is used for each operating cost element in this example and in each of the other reactor-fuel combination estimates.

The resulting relative cost comparisons for all combinations are presented in Table 7. These include the adjustments for fuel diameter and density for the tubular rod assemblies. There are no such adjustments for the HTGR fuel elements since a common design was considered for the base case and each of the alternative fuel selections. Note that there are minor differences between this table and a similar table given by Kasten et $a 1.1$ These are the result of arithmetical errors discovered during the preparation of our report, rather than changes in the estimating procedure or evaluation made at that time. The two significant errors are associated with the $\left({ }^{2}{ }^{3} \mathrm{U}, \mathrm{Th}\right) \mathrm{O}_{2}$ fuel for a LWR and a gascooled FBR where the effects of fuel density were not included in the original estimate. This consideration increases the total factor by 
Table 6. Capital Cost Considerations

A. Building

1. Environmental containment

2. Safeguards

3. Mode of operation and maintenance

(A) Contact

(B) Lightly shielded

(C) Heavily shielded

4. Process area environment

(A) Air

(B) Inert

5. Process complexity

B. Equipment

1. Environmental containment

2. Safeguards

3. Mode of operation and maintenance

(A) Contact

(B) Lightly shielded

(C) Heavily shielded

4. Process area environment

(A) Air

(B) Inert

5. Process complexity

6. Criticality considerations

7. Accountability requirements

8. Degree of automation 
Table 7. Relative Fabrication Cost Comparison ${ }^{a}$

\begin{tabular}{|c|c|c|c|c|c|}
\hline \multirow{2}{*}{$\begin{array}{l}\text { Reactor } \\
\text { Fuel }\end{array}$} & \multirow{2}{*}{$\begin{array}{c}\text { Fuel } \\
\text { Material }\end{array}$} & \multicolumn{4}{|c|}{ Relative Cost Factors } \\
\hline & & Capital & Hardware & Operating & Total \\
\hline \multicolumn{6}{|l|}{ Part A } \\
\hline \multirow[t]{5}{*}{ LWR（PWR） } & $\left({ }^{2}{ }^{35} \mathrm{U}, \mathrm{U}\right) \mathrm{O}_{2}$ & 0.33 & 0.38 & 0.29 & $1.00^{b}$ \\
\hline & $(\mathrm{Pu}, \mathrm{U}) \mathrm{O}_{2}$ & 1.49 & 0.38 & 1.45 & 3.32 \\
\hline & $\left({ }^{2}{ }^{5} \mathrm{U}, \mathrm{Th}\right) \mathrm{O}_{2}$ & 0.41 & 0.42 & 0.44 & 1.27 \\
\hline & $\left({ }^{2}{ }^{3}{ }^{3} \mathrm{U}, \mathrm{Th}\right) \mathrm{O}_{2}$ & 2.18 & 0.42 & 1.60 & 4.19 \\
\hline & $(\mathrm{Pu}, \mathrm{Th}) \mathrm{O}_{2}$ & 1.49 & 0.38 & 1.53 & 3.40 \\
\hline \multirow[t]{4}{*}{ CANDU } & Natural $\mathrm{UO}_{2}$ & 0.33 & 0.09 & 0.11 & 0.53 \\
\hline & $(\mathrm{Pu}, \mathrm{U}) \mathrm{O}_{2}$ & 1.49 & 0.09 & 0.50 & 2.08 \\
\hline & $\left({ }^{2}{ }^{3}{ }^{3} \mathrm{U}, \mathrm{Th}\right) \mathrm{O}_{2}$ & 1.98 & 0.12 & 0.55 & 2.65 \\
\hline & $(\mathrm{Pu}, \mathrm{Th}) \mathrm{O}_{2}$ & 1.49 & 0.09 & 0.55 & 2.13 \\
\hline \multirow[t]{3}{*}{ LMFBR } & $(\mathrm{Pu}, \mathrm{U}) \mathrm{O}_{2}$ & 3.19 & 0.58 & 2.10 & 5.87 \\
\hline & $(\mathrm{Pu}, \mathrm{U}) \mathrm{C}$ & 2.68 & 0.37 & 1.66 & 4.72 \\
\hline & $2{ }^{3}{ }^{3} \mathrm{U}, \mathrm{Th}$ & 2.73 & 0.35 & 1.61 & 4.69 \\
\hline \multirow[t]{3}{*}{ GFBR } & $(\mathrm{Pu}, \mathrm{U}) \mathrm{O}_{2}$ & 3.19 & 0.90 & 2.29 & 6.38 \\
\hline & $\left({ }^{2}{ }^{3}{ }^{3} \mathrm{U}, \mathrm{Th}\right) \mathrm{O}_{2}$ & 5.01 & 0.99 & 2.64 & 8.64 \\
\hline & $(\mathrm{Pu}, \mathrm{Th}) \mathrm{O}_{2}$ & 3.64 & 0.90 & 2.40 & 6.94 \\
\hline \multicolumn{6}{|l|}{ Part B } \\
\hline \multirow[t]{4}{*}{ HTGR } & $2{ }^{35} \mathrm{UO}_{2}-\mathrm{ThO}_{2}$ & 0.26 & 0.42 & 0.32 & $1.00^{c}$ \\
\hline & $23^{3} \mathrm{UCO}-\mathrm{ThO}_{2}$ & 1.23 & 0.42 & 0.96 & 2.61 \\
\hline & $2{ }^{35} \mathrm{UO}_{2}-\mathrm{UO}_{2}$ & 0.23 & 0.35 & 0.32 & 0.90 \\
\hline & $\mathrm{PuO}_{2}-\mathrm{ThO}_{2}$ & 1.23 & 0.42 & 0.96 & 2.61 \\
\hline \multicolumn{6}{|c|}{ 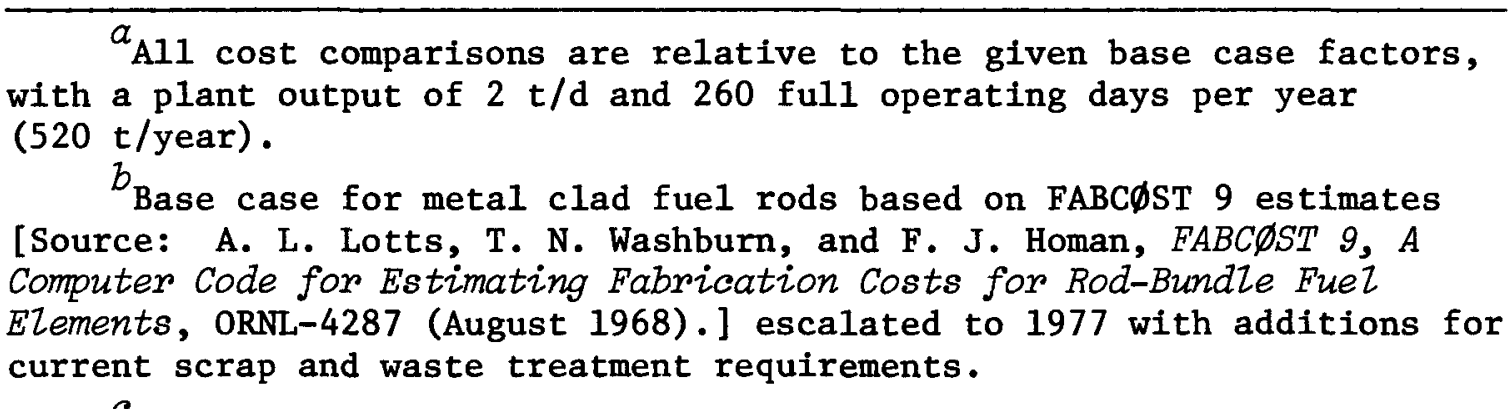 } \\
\hline
\end{tabular}


about $10 \%$ for these two cases and therefore was consldered too small to warrant publication of errata for the above report.

The legislative restrictions on environmental releases are currently well defined. However, the current restrictions on personnel exposures are under review. Experience with limited plutonium production has indicated that current operational exposure restrictions are difficult to meet. As a result of a reduction in the allowable exposure level, all fabrication processes using plutonium were assumed to be done remotely in facilities equipped for remote maintenance.

\section{COST NORMALIZATION}

As indicated earlier, our fabrication cost estimate data was to be used by others to study the relative merits of different fuels within a given reactor and to eventually compare different reactor-fuel combinations. Thus, it was necessary to reduce the relative cost estimates to a dollar basis. Further, since different reactors require different fuel quantities and all fabrication costs vary with plant capacity, some means had to be derived for scaling costs as a function of demand, which would establish the plant capacities. In this section we will address how we established a dollar value for each of the base case reactor-fuel combinations and the proposed scaling factors.

Cost Estimates for Metal Clad Cylindrical Fuel Rod Types

The LWR (PWR) fueled with low-enriched $\mathrm{UO}_{2}$ was chosen earlier for the base case for all fuel assemblies containing cylindrical metal clad fuel rods. Although there are several manufacturing plants in operation, the necessary cost data for fabrication of this fuel are not readily available. Therefore, the detalled cost estimates ${ }^{3}$ made in 1968 were updated to form the new base case costs.

The available data from the earlier estimate for fabrication of low-enriched $\mathrm{UO}_{2}$ for a PWR reactor in a plant with a capacity of $2-t \mathrm{HM} / \mathrm{d}$ throughout and a 260 d/year operating schedule were (in 1968 dollars): 
$\begin{array}{ll}\text { Capital cost (at a } 30 \% \text { fixed charge rate) } & =\$ 15 / \mathrm{kg} \mathrm{HM} \\ \text { Hardware cost } & =\$ 26 / \mathrm{kg} \mathrm{HM} \\ \text { Operating cost } & =\$ 14 / \mathrm{kg} \mathrm{HM}\end{array}$

Since these estimates were for plants constructed under the rules and regulations in effect in 1968, the estimates were modified to conform to current licensing requirements. Consequently, the capital costs were increased by $50 \%$ to accommodate current requirements for natural disaster phenomena, such as earthquakes and tornadoes; to provide the high level of physical security and accountability to comply with safeguards requirements; and to incorporate the necessary facilities and equipment to provide for scrap recovery, no liquid effluent release, and solid waste treatment and packaging. We also corrected the operating costs to accommodate the new operations. The initial manpower loading of 1011 men was increased to 1411 . The additional personnel were divided equally between the two activities of scrap recovery and waste treatment for estimating convenfence, although it is recognized that some of the additions would be distributed over all process activities.

The modified base cost was escalated to the 1977 level. The escalation was based on the official Energy Research and Development AgencyOak Ridge Operations office (ERDA-ORO) escalation modifier for the years 1968 to 1977 - 2.164 .

The resulting base case estimate in 1977 dollars is:

$\begin{array}{ll}\text { Capital cost (at a } 30 \% \text { fixed charge rate) } & =\$ 48.70 / \mathrm{kg} \\ \text { Hardware cost } & =\$ 56.26 / \mathrm{kg} \\ \text { Operating cost } & =\frac{\$ 42.20 / \mathrm{kg}}{\$ 147.16 / \mathrm{kg}} \\ \quad \text { Total } & \end{array}$

This total rounded to $\$ 150 / \mathrm{kg}$.

Cost Estimates for Prismatic HTGR Fuel Elements

Unlike the metal clad cylindrical fuel rod containing assemblies, a base cost estimate for the fresh fuel fabrication costs for HTGR fuels was not readily available. General Atomic Company was known to have made such studies; but like the data for current LWR production facilities, 
such Information is proprietary. However, an ERDA draft document ${ }^{4}$ was available from which most of the cost information could be derived for a recycle fuel fabrication plant.

The ERDA study was based on a low-capacity demonstration facility; but the capital cost information had been derived from an earlier conceptual design study for a commercial-scale plant with a capacity slightly less than $1 \mathrm{t} / \mathrm{d}$ (Target Recycle Plant). The following is a description of the derivation of the capital cost increment for a $2-t / d$ recycle plant from this information.

A capital investment of $\$ 706$ million was quoted for a total recycle demonstration plant. The figure was reportedly derived by escalating the commercial plant conceptual design and cost estimate by $10 \%$ to convert from 1975 to 1976 dollars and by using a scaling factor of 0.74 for capacity reduction. Since this escalation rate was inconsistent with the ERDA-ORO rates and we wished to work with the higher capacity plant values, these modifications were reversed.

Thus, the capital investment for the commercial plant was calculated in 1975 dollars as

$$
706 \times 10^{6} / 1.1(0.74)=\$ 867 \times 10^{6} .
$$

Then, from avallable Information we assigned $50 \%$ of the total capital cost to the refabrication portion of the recycle plant and escalated the costs to 1977 dollars by using the ERDA-ORO escalation factor:

$$
\left(867 \times 10^{6} / 2\right) \times 1.332=\$ 577.4 \text { million } .
$$

This gave the cost for a fabrication facility with a capacity of 25,000 fuel elements per year. A 2-t HM/d plant operating $260 \mathrm{~d} / \mathrm{y}$ will produce 54,300 fuel elements per year (based on an average of $9.57 \mathrm{~kg}$ HM per fuel element). The capital cost (in 1977 dollars) for the 2-t/d plant was estimated as follows:

$$
\$ 577 \text { million }(54,300 / 25,000)^{0.5}=\$ 851 \text { million } .
$$


We used a factor of 0.5 rather than the 0.4 from the reference study because of the high level of mechanical equipment in the refabrication area that will require duplication rather than increased capacity.

A capital charge in $\$ / \mathrm{kg}$ HM was calculated by using the $30 \% \mathrm{flxed}$ charge rate that was applied to the capital costs for the metal clad fuels and an annual capacity of $0.52 \mathrm{Gg}$. This provided a capital cost of $\$ 490 / \mathrm{kg} \mathrm{HM}$.

Hardware cost data were also available in the same report; however, some estimates appeared to be too low. Both the reference information and the revised estimates are presented in Table 8. Since the major difference is associated with the cost of the graphite block and no information based on large-scale operations is available, a compromise hardware estimate of $\$ 168 / \mathrm{kg}$ HM was used for this study.

Operating cost data were also derived from the Alternate Program $\mathrm{P} 1 \mathrm{an}$. The estimate in the document was $\$ 26$ million per year for a production rate of 7600 fuel elements. The costs were $\$ 6$ million expendables and $\$ 20$ million for manpower. This estimate reduces to $\$ 357 / \mathrm{kg}$ in 1976 dollars or $\$ 379 / \mathrm{kg}$ in 1977 dollars. At the time these estimates were made, we did not attempt to correct the manpower costs for the increased scale of production. Consequently, the operating costs are probably conservative.

The final dollar value for the prismatic HTGR elements can be summarized for the ${ }^{23} 3 \mathrm{UCO}-\mathrm{ThO}_{2}$ remotely fabricated fuel as:

\section{$\underline{\$ / \mathrm{kg} \mathrm{HM}}$}

$\begin{array}{cr}\text { Capital cost } & 490 \\ \text { Hardware cost } & 168 \\ \text { Operating cost } & 379 \\ \text { Total } & \$ 1037\end{array}$

This cost was divided by the ratio of the relative cost factors for the ${ }^{235} \mathrm{UO}_{2}-\mathrm{ThO}_{2}$ and the ${ }^{233} \mathrm{UCO}-\mathrm{ThO}_{2}$ fuels. The resulting $\$ 402 / \mathrm{kg} \mathrm{HM}$ was rounded to $\$ 400$ and used as the base case cost for this fuel element. 
Table 8. Hardware Cost Estimates for HTGR Prismatic Fuel Elements

\begin{tabular}{|c|c|c|c|c|}
\hline \multirow[b]{2}{*}{ Item } & \multicolumn{2}{|c|}{ Alternate Program $\mathrm{Plan}^{a}$} & \multicolumn{2}{|c|}{ Current Estimate ${ }^{b}$} \\
\hline & $\begin{array}{c}\text { Unit Costs } \\
\text { (\$/Fuel Element) }\end{array}$ & $\$ / \mathrm{kg} \mathrm{HM}$ & Unit Cost & $\$ / \mathrm{kg} \mathrm{HM}$ \\
\hline Graphite block and plugs & 784 & 81.91 & $\begin{array}{c}\$ 1500 / \text { fuel } \\
\text { element }\end{array}$ & 156 \\
\hline Fertile coated particles & 190 & 19.85 & $\$ 40 / \mathrm{kg}$ & 42 \\
\hline Shim particles & 88 & 9.19 & $\$ 68 / \mathrm{kg}$ & 39 \\
\hline \multicolumn{5}{|l|}{ Miscellaneous } \\
\hline Poison & 6 & 0.63 & & \\
\hline Matrix & 5 & 0.52 & & - \\
\hline Totals & & 112.10 & & 238 \\
\hline
\end{tabular}

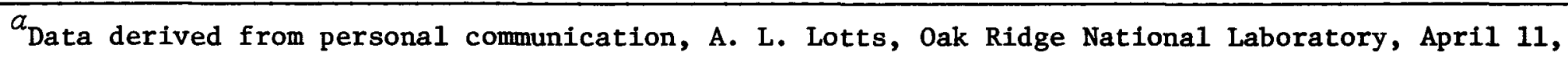
1975.

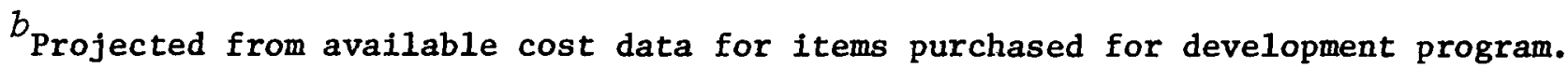


Effects of Plant Capacity on Fabrication Costs

Different types of reactors and different reactor build scenarios both affect required fuel fabrication capacity. Since the cost of fabrication depends on fabrication plant capacity, we established scaling factors to adjust the base case 2-t HM/d capacity costs to a variety of capacities based on fuel fabrication demand.

Although each of the three components comprising the total fabrication costs scale with capacity at different rates, the needs of the study were best met with a single capacity factor applied to the total costs. Again, we referred to the earlier detailed FABC $\emptyset \mathrm{ST} 9$ study $^{3}$ to obtain the appropriate factors. Table 9 lists the scaling factors for each component of the cost as well as the weighted total for different fabrication capacities from Appendix $F$ of the above report. Although this case dealt specifically with carbide fuels for an LMFBR, similar factors were calculated for other cases in the early study. The actual scaling factors in our study are in Table 10. These factors have also been plotted ${ }^{6}$ and were compared with some known cost data at the time of that report.

Scaling factors, particularly those applicable to capital costs, are affected by such things as batch and lot size restrictions resulting from criticality considerations, etc., so that different factors apply to different reactor-fuel combinations. However, we did not refine our estimates to account for this.

\section{UNIT COST ESTIMATION SUMMARY}

Our cost estimation net results are summarized in Table 11. The cost estimates are based on a given fuel element design for each reactor-fuel combination. Minor changes in element design parameters can be accommodated with the fuel element design parameter corrections for the metal clad cylindrical fuel rod assemblies, but major changes would require reevaluation. The relative cost factors are considered more accurate than the absolute dollar costs. The accuracy is limited 
Table 9. Effects of Plant Capacity on Fuel Fabrication Costs ${ }^{a}$

\begin{tabular}{ccccc}
\hline \multirow{2}{*}{$\begin{array}{c}\text { Plant Capacity } \\
(\mathrm{t} \mathrm{HM} / \mathrm{d})\end{array}$} & $\begin{array}{c}\text { Capital } \\
\text { Costs }\end{array}$ & $\begin{array}{c}\text { Hardware } \\
\text { Costs }\end{array}$ & $\begin{array}{c}\text { Operating } \\
\text { Costs }\end{array}$ & $\begin{array}{c}\text { Weighted } \\
\text { Costs }\end{array}$ \\
\hline 0.5 & 1.67 & 1.21 & 1.62 & 1.46 \\
0.75 & 1.42 & 1.14 & 1.38 & 1.29 \\
1.0 & 1.28 & 1.09 & 1.25 & 1.19 \\
1.5 & 1.10 & 1.04 & 1.09 & 1.07 \\
2.0 & 1.00 & 1.00 & 1.00 & 1.00 \\
3.0 & 0.87 & 0.95 & 0.89 & 0.91 \\
4.0 & 0.79 & 0.92 & 0.83 & 0.86 \\
5.0 & 0.70 & 0.89 & 0.76 & 0.79 \\
6.0 & 0.64 & 0.86 & 0.72 & 0.75 \\
7.0 & 0.60 & 0.84 & 0.69 & 0.73 \\
\hline
\end{tabular}

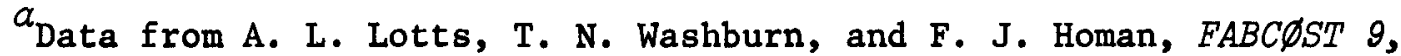
A Computer Code for Estimating Fabrication Costs for Rod-Bundle Fuel Elements, ORNL-4287 (August 1968).

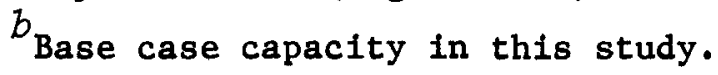

Table 10. Fabrication Cost as a Function of Processing Rate

\begin{tabular}{cc}
$\begin{array}{c}\text { Rate } \\
(t \text { HM/d })\end{array}$ & $\begin{array}{c}\text { Cost } \\
\text { Fraction }\end{array}$ \\
\hline 0.5 & 1.53 \\
1.0 & 1.23 \\
2.0 & 1.00 \\
3.0 & 0.90 \\
4.0 & 0.84 \\
5.0 & 0.79 \\
6.0 & 0.76 \\
7.0 & 0.73 \\
\hline
\end{tabular}


Table 11. Estimated Fabrication Cost Comparison ${ }^{a}$ Summary

\begin{tabular}{|c|c|c|c|c|c|c|}
\hline \multirow{2}{*}{$\begin{array}{c}\text { Reactor } \\
\text { Type }\end{array}$} & \multirow{2}{*}{$\begin{array}{c}\text { Fuel } \\
\text { Material }\end{array}$} & \multicolumn{4}{|c|}{ Relative Cost Factors } & \multirow{2}{*}{$\begin{array}{c}\text { Estimated } \\
\text { Costs } \\
(\$ / \mathrm{kg})^{b}\end{array}$} \\
\hline & & Capital & Hardware & Operating & Tota1 & \\
\hline \multicolumn{7}{|l|}{ Part A } \\
\hline \multirow[t]{5}{*}{ LWR (PWR) } & $\left({ }^{2}{ }^{5} \mathrm{U}, \mathrm{U}\right) \mathrm{O}_{2}$ & 0.33 & 0.38 & 0.29 & 1.00 & $150^{c}$ \\
\hline & $(\mathrm{Pu}, \mathrm{U}) \mathrm{O}_{2}$ & 1.49 & 0.38 & 1.45 & 3.32 & 500 \\
\hline & $\left({ }^{235} \mathrm{U}, \mathrm{Th}\right) \mathrm{O}_{2}$ & 0.41 & 0.42 & 0.44 & 1.27 & 190 \\
\hline & $\left({ }^{2}{ }^{3}{ }^{3} \mathrm{U}, \mathrm{Th}\right) \mathrm{O}_{2}$ & 2.18 & 0.42 & 1.60 & 4.19 & 630 \\
\hline & $(\mathrm{Pu}, \mathrm{Th}) \mathrm{O}_{2}$ & 1.49 & 0.38 & 1.53 & 3.40 & 510 \\
\hline \multirow[t]{4}{*}{ CANDU } & Normal $\mathrm{UO}_{2}$ & 0.33 & 0.09 & 0.11 & 0.53 & 80 \\
\hline & $(\mathrm{Pu}, \mathrm{U}) \mathrm{O}_{2}$ & 1.49 & 0.09 & 0.50 & 2.08 & 310 \\
\hline & $\left({ }^{2}{ }^{3}{ }^{3} \mathrm{U}, \mathrm{Th}\right) \mathrm{O}_{2}$ & 1.98 & 0.12 & 0.55 & 2.65 & 400 \\
\hline & $(\mathrm{Pu}, \mathrm{Th}) \mathrm{O}_{2}$ & 1.49 & 0.09 & 0.55 & 2.13 & 320 \\
\hline \multirow[t]{3}{*}{ LMFBR } & $(\mathrm{Pu}, \mathrm{U}) \mathrm{O}_{2}$ & 3.19 & 0.58 & 2.10 & 5.87 & 880 \\
\hline & $(\mathrm{Pu}, \mathrm{U}) \mathrm{C}$ & 2.68 & 0.37 & 1.66 & 4.72 & 710 \\
\hline & $23^{3} \mathrm{U}, \mathrm{Th}$ & 2.73 & 0.35 & 1.61 & 4.69 & 700 \\
\hline \multirow[t]{3}{*}{ GFBR } & $(\mathrm{Pu}, \mathrm{U}) \mathrm{O}_{2}$ & 3.19 & 0.90 & 2.29 & 6.38 & 960 \\
\hline & $\left({ }^{2}{ }^{3}{ }^{3} \mathrm{U}, \mathrm{Th}\right) \mathrm{O}_{2}$ & 5.01 & 0.99 & 2.64 & 8.64 & 1300 \\
\hline & $(\mathrm{Pu}, \mathrm{Th}) \mathrm{O}_{2}$ & 3.64 & 0.90 & 2.40 & 6.94 & 1040 \\
\hline \multicolumn{7}{|l|}{ Part B } \\
\hline \multirow[t]{4}{*}{ HTGR } & $2{ }^{35} \mathrm{UO}_{2}-\mathrm{ThO}_{2}$ & 0.26 & 0.42 & 0.32 & 1.00 & $400^{d}$ \\
\hline & $2{ }^{3}{ }^{3} \mathrm{UCO}-\mathrm{ThO}_{2}$ & 1.23 & 0.42 & 0.96 & 2.61 & 1030 \\
\hline & ${ }^{2}{ }^{3} \mathrm{UO}_{2}-\mathrm{UO}_{2}$ & 0.23 & 0.35 & 0.32 & 0.90 & 360 \\
\hline & $\mathrm{PuO}_{2}-\mathrm{ThO}_{2}$ & 1.23 & 0.42 & 0.96 & 2.61 & 1030 \\
\hline
\end{tabular}

$a_{\mathrm{A} 11}$ cost comparisons are relative to the given base case factors.

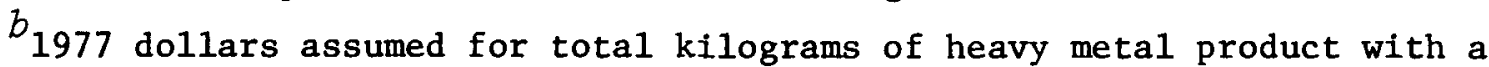
plant output of $2 \mathrm{t} / \mathrm{d}$ and operating $260 \mathrm{~d} /$ year $(520 \mathrm{t} /$ year $)$.

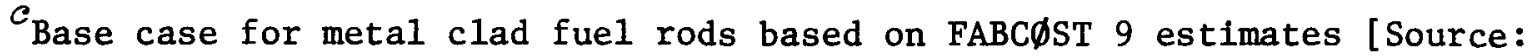
A. L. Lotts, T. N. Washburn, and F. J. Homan, FABCØST 9, A Computer Code for Estimating Fabrication Costs for Rod-Bundle Fuel Elements, ORNL-4287 (August 1968).] escalated to 1977 with additions for current scrap and waste treatment requirements.

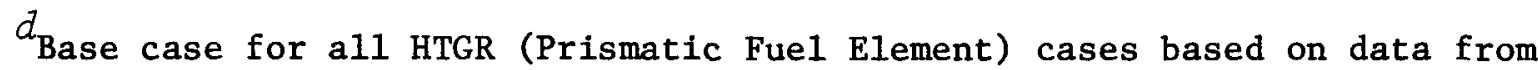
personal communication, A. L. Lotts, Oak Ridge National Laboratory, Apri1 11, 1975. 
by the lack of plant designs, operating experience, etc., and is, therefore, estimated to be about $\pm 25 \%$.

All costs are for a common plant design capacity of 2-t HM/d product with a capital cost increment based on a fixed charge rate of $30 \%$. Although the dollar values represent a cost to the reactor in 1977 dollars, they are in fact a price from the fuel manufacturer's point of view since they include a return on investment. The fixed charge rate appears to be reasonable but is near the high side of the range (15-36\%) for such rates quoted in the GESMO report. 31

Although we referred to some previous studies and cost estimates ${ }^{2}, 3,6$ in developing the factors for the categories and increments, we did not attempt to normalize the estimates in this study to any of the earlier estimates. Such normalization would be essentially impossible since the rationale of each reference was not avallable and could have adversely affected our intent to provide a consistent set of estimates for comparative evaluation.

The estimates in this study can be improved and the uncertainties reduced only by extensive additional effort. This effort should be directed in four areas:

1. commercial involvement in the review and improvement of the existing estimates,

2. development of conceptual plant layouts and cost estimates with which to define the capital cost component,

3. improved definition of production requirements, and

4. stabilization of NRC requirements. Current uncertainties require conservative approaches in terms of production worker protection and safeguards requirements.

\section{ACKNOWLEDGMENTS}

Compilation of the information needed to develop these cost estimates would have been impossible in our short schedule without the assistance and cooperation of a number of people. In particular, I would like to recognize the assistance provided by F. J. Homan in providing the information from the early FABC $\varnothing \mathrm{ST} 9$ computer estimates; E. H. Gift for 
providing information on the CANDU; J. D. Sease for providing information on commercial LMFBR designs and consultation on fabrication processes; E. S. Bomar for consultation on the carbide fuel fabrication processes; C. D. Watson and F. L. Peiskel for providing significant information on element hardware weights; and $P$. Wilson for helping with the composition of many of the tables, organization of the report, and initial draft typing. Finally I would like to thank B. G. Ashdown for editing the report and Ethel Cagle for preparing the manuscript for publication. 


\section{REFERENCES}

1. P. R. Kasten et al., Assessment of the Thorizm Fuel Cycle in Power Reactors, ORNL/TM-5565 (January 1977).

2. A. L. Lotts and T. N. Washburn, "Use of Computer Codes in Estimating Fuel Element Fabrication Costs," Nucl. Appl. Technol. 4(5): 307-19 (May 1968).

3. A. L. Lotts, T. N. Washburn, and F. J. Homan, FABCøST 9, A Computer Code for Estimating Fabrication Costs for Rod-Bundle Fuel Elements, ORNL-4287 (August 1968).

4. H. E. Williams on and D. C. Ditmore, "Current BWR Fuel Design and Experience," React. Technol. 14(1): 68-98 (Spring 1971).

5. H. H. Keepfer, R. B. Richards, and T. Trock1, "Fuel Performance in the BWR," Proc. Am. Power Conf. 34: 169-78 (1972).

6. Personal Communication, A. L. Lotts, Oak RIdge National Laboratory, Apri1 11, 1975.

7. Quanicasse Units 1 and 2, Preliminary Safety Analysis Report, Consumer Power Company, Vol. 4., NRC Docket 0475, 1974.

8. A. L. Lotts et a1., "Status of Thermal Reactor Fuel Manufacture in the United States," pp. 201-14 in Peacefuz Uses of Atomic Energy, Proc. 4th Int. Conf., Geneva, 1971, Vol. 8, United Nations, N. Y., and International Atomic Energy Agency, Vienna, 1972.

9. C. L. Moon, "Pickering Generating Station," Nucl. Eng. Int. 19(3): 501-5 (1970).

10. P. C. Löken, "Core Physics," Nucl. Eng. Int. 19(3): 506-7 (1970).

11. G. R. Fanjoy and A. S. Bain, "Fuel and Fuel Cycle," Nucl. Eng. Int. 19(3): 514-18 (1970).

12. E. R. Appleby, Compilation of Data and Descriptions for United States and Foreign Liquid Metal Fast Breeder Reactors, Sect. XVI, HEDL-TME 75-12 (August 1975).

13. E. R. Appleby, Compization of Data and Descriptions for United States and Foreign Liquid Metal Fast Breeder Reactors, Sect. XVII, HEDL-TME 75-12 (August 1975).

14. J. J. Taylor, "Westinghouse Project Overview," p. 6-14 in Proposed Reference Design for the Clinch River Breeder Reactor Plant, PMC-74-02, 1974. 
15. Personal communication, P. M. French, Westinghouse Corporation, Pittsburgh, Pa., to J. D. Sease, Oak Ridge National Laboratory (date unknown).

16. P. R. Doherty et al., "Optimum Pin Diameter for LMFBR Advanced Fuels," paper presented at American Nuclear Soclety Winter Meeting, Washington, D.C., October 27-31, 1974.

17. J. A. Horak et al., "The Effects of Irradiation on Some Binary Alloys of Thorium-Plutonium and Zirconium-Plutonium," ANL-6428 (July 1962).

18. J. H. Kittel et al., "Effects of Irradiation on Thorium and ThoriumUranium Alloys," ANL-5674 (April 1963).

19. B. Blumentha1, J. E. Penachi, D. E. Busch, and D. R. O'Boyle, "Thorium-Uranfum-P1utonfum Alloys as Potential Fast Power-Reactor Fuels. Part II. Properties and Irradiation Behavior of ThoriumUranium-P1utonium A1loys," ANL-7259, 1969.

20. R. P. Hammond et al., The Unclad-Metal Breeder Reactor (UMBR) for Desalting or Power, ORNL-4202 (January 1969).

21. B. R. Sehgal, C. Lin, J. Naser, and W. B. Lowenstein, "Thorium-Based Fuels in Fast Breeder Reactors," Trans. Am. Nucl. Soc. 21(1): 422 (June 1975).

22. Project Staff, $300 \mathrm{MW}(e)$ Gas-Cooled Fast Breeder Reactor Demonstration Plant, GA-A13045 (Proprietary) (June 15, 1974).

23. A. M. Perry and A. M. Weinberg, "Thermal Breeder Reactors," Ann. Rev. Nucl. Sci. 22: 317-54 (1972).

24. H. G. Rickover, "Naval Nuclear Propulsion Program - 1975," testimony at hearing before the Subcommittee on Legislation of the Joint Committee on Atomic Energy, Congress of the United States, March 5, 1975.

25. Safety Analysis Report for the Light Water Reactor Breeder, Shippingport Atomic Power Station, Vols. 1-10.

26. M. Benedict and T. H. Pigford, Nuclear Chemical Engineering, McGraw-Hi11, N. Y., 1957.

27. E. N. Pearson, SRE Systems and Components Experience, Core II, USAEC Report NAA-SR-MEMO-9003 (November 15, 1963).

28. J. D. Sease and A. L. Lotts, Development of Processes and Equipment for the Refabrication of HTGR FueZs, ORNL/TM-5334 (June 1976). 
29. John E. T111, Assessment of the Radiological Impact of ${ }^{232} \mathrm{U}$ and Daughters in $233_{U}$ HTGR Fuel, ORNL/TM-5049 (February 1976).

30. Atomlc Energy Commission, Transuranic Waste Disposal Proposed Standards for Protection against Radiation (10 CFR P. 20), Fed. Regis. 39(178): pp. 35821-23 (September 12, 1974).

31. U. S. Nuclear Regulatory Commission, Final Generic Enviroronental Statement on the Use of Recycle Plutonium in Mixed-Oxide Fuel in Light Water Cooled Reactors, Vo1. 4, NUREG-0002, Draft (August 1974). 
APPENDIX A - DESCRIPTIVE DATA FOR FUEL ELEMENTS USED IN COST ESTIMATES

The assumed reference designs for each reactor type and fuel combination have been collected in tabular form. These are given in the following tables. 
0 
Table Al. Pressurized-Water Reactor Fuel Element Design Description ${ }^{a}$

\begin{tabular}{|c|c|}
\hline Component & Description \\
\hline \multicolumn{2}{|c|}{ Assembly } \\
\hline Geometry & $17 \times 17$ square \\
\hline End fitting material & 304 ss \\
\hline End fitting mass, kg (total) & 10 \\
\hline Grid spacers & 8 \\
\hline Grid spacer mass, kg (tota 1 ) & 5.5 \\
\hline Assemb1y length, m & 4.06 \\
\hline Assemb1y gross mass, kg & 668.6 \\
\hline Fuel rods per assembly & 264 \\
\hline Thimble tubes per assembly & 24 \\
\hline $\begin{array}{l}\text { Instrument tubes per } \\
\text { assembly }\end{array}$ & 1 \\
\hline Enrichments per assembly & 1 \\
\hline \multicolumn{2}{|l|}{$\begin{array}{l}\text { Structural materials per } \\
\text { assembly, } \mathrm{kg}\end{array}$} \\
\hline 304 SS & 10 \\
\hline Zircaloy -4 & 130 \\
\hline A11oy 718 & 5.5 \\
\hline \multicolumn{2}{|c|}{ Fuel Rods } \\
\hline Cladding material & Zircaloy -4 \\
\hline $\begin{array}{l}\text { Cladding outside } \\
\text { diameter, mm }\end{array}$ & 9.50 \\
\hline $\begin{array}{l}\text { Cladding inside } \\
\text { diameter, mm }\end{array}$ & 8.36 \\
\hline Cladding length, m & 3.85 \\
\hline Fuel material & $\mathrm{UO}_{2}$ \\
\hline Fuel form & $\begin{array}{l}\text { Right circular cylinder } \\
\text { pellets }\end{array}$ \\
\hline Fuel diameter, mm & 8.19 \\
\hline Fuel stack height, m & 3.65 \\
\hline Fuel density, $\mathrm{Mg} / \mathrm{m}^{3}$ & 10.41 \\
\hline
\end{tabular}


Table Al (continued)

\begin{tabular}{|c|c|}
\hline Component & Description \\
\hline \multicolumn{2}{|c|}{ Fuel Rods } \\
\hline \multicolumn{2}{|l|}{ Enrichment, \% } \\
\hline Region 1 & $\sim 2.1$ \\
\hline Region 2 & $\sim 2.6$ \\
\hline Region 3 & 23.2 \\
\hline End caps & Zircaloy-4 \\
\hline Fuel-to-cladding thermal bond & $\mathrm{He}+\mathrm{Ar}$ \\
\hline Approximate pressure, $\mathrm{MPa}$ & 4.03 \\
\hline psi & 585 \\
\hline \multicolumn{2}{|c|}{ Reactor Requirements } \\
\hline Fuel assemblies in core & 193 \\
\hline Frequency of reloading & Annual \\
\hline Fuel assemblies per reload & 64 \\
\hline Burnup at discharge, MWd/t & 33,000 \\
\hline $\mathrm{TJ} / \mathrm{kg}$ & 2.9 \\
\hline
\end{tabular}


Table A2. Boiling-Water Reactor Fuel Element Design Description

\begin{tabular}{|c|c|}
\hline Component & Description \\
\hline \multicolumn{2}{|c|}{ Assembly } \\
\hline Geometry & $8 \times 8$ square \\
\hline Channel material & Zircaloy-4 \\
\hline Channe1 thickness, mm & $2.03-2.54$ \\
\hline End fitting material & 304 ss \\
\hline End fitting mass, $\mathrm{kg}$ (total) & 8.2 \\
\hline Grid spacers & 7 \\
\hline Grid spacer material & $\begin{array}{l}\text { Zircaloy-4 (Inconel } \\
\text { springs) }\end{array}$ \\
\hline \multicolumn{2}{|l|}{ Grid spacer mass } \\
\hline Assembly length, m & 4.47 \\
\hline Assembly gross mass, $\mathrm{kg}$ & 279 \\
\hline Fuel rods per assembly & 63 \\
\hline Enrichments per assembly & 4 (Typical) \\
\hline $\begin{array}{l}\text { Heavy metal per assembly, } \mathrm{kg} \\
\text { Structural materials, } \mathrm{kg}\end{array}$ & 189 \\
\hline 304 SS & 8.2 \\
\hline Zircaloy-4 & 56.7 \\
\hline \multicolumn{2}{|c|}{ Fuel Rods } \\
\hline Cladding material & Zircaloy-2 \\
\hline Cladding outside diameter, mm & 12.52 \\
\hline Cladding length, m & 4.06 \\
\hline Fuel material & $\mathrm{UO}_{2}$ \\
\hline Fuel form & $\begin{array}{l}\text { Right circular cylinder } \\
\text { pellets }\end{array}$ \\
\hline Fuel diameter, mm & 12.45 \\
\hline Fuel stack height, m & 3.76 \\
\hline Fuel density, $\mathrm{Mg} / \mathrm{m}^{3}$ & 10.41 \\
\hline Fuel enrichment, $\%$ & $\sim 2.6$ (Average) \\
\hline End caps & Zircaloy-2 \\
\hline
\end{tabular}


Table A2 (continued)

\begin{tabular}{cl}
\hline \multicolumn{1}{c}{ Component } & \multicolumn{1}{c}{ Description } \\
\hline & Fuel Rods \\
Fuel rod internals & \\
Spring & $302 \mathrm{sS}$ \\
Getter & $\begin{array}{l}\text { Proprietary } \\
\text { He (slight positive } \\
\text { pressure) }\end{array}$ \\
\hline
\end{tabular}


Table A3. CANDU Fuel Element Design Description

\begin{tabular}{|c|c|}
\hline Component & Description \\
\hline \multicolumn{2}{|c|}{ As sembly } \\
\hline Geometry & Circular \\
\hline End fitting material & Zircaloy -2 \\
\hline Assembly length, $\mathfrak{m}$ & 0.495 \\
\hline Assembly gross mass, $\mathrm{kg}$ & 24.8 \\
\hline Fuel rods per assembly & 28 \\
\hline Heavy metal per assembly, $\mathrm{kg}$ & 19.9 \\
\hline Structural material mass, $\mathrm{kg}$ & 2.1 \\
\hline \multicolumn{2}{|c|}{ Fue1 Rods } \\
\hline Cladding material & Zircaloy -4 \\
\hline Cladding outside diameter, $\mathrm{mm}$ & 15.2 \\
\hline Cladding inside diameter, $\mathrm{mm}$ & 14.4 \\
\hline Cladding length, $\mathrm{m}$ & 0.49 \\
\hline Fuel material & $\mathrm{UO}_{2}$ \\
\hline Fuel form & $\begin{array}{l}\text { Right circular cylinder } \\
\text { pellets }\end{array}$ \\
\hline Fue1 diameter, mm & 14.4 \\
\hline Fuel density, $\mathrm{Mg} / \mathrm{m}^{3}$ & 10.55 \\
\hline Enrichment & 0.711 (Natural U) \\
\hline Fue1-to-cladding thermal bond & $\begin{array}{l}\text { He (slight positive } \\
\text { pressure) }\end{array}$ \\
\hline \multicolumn{2}{|c|}{ Reactor Requirements } \\
\hline \multicolumn{2}{|l|}{ Initial core assemblies } \\
\hline Frequency of reloading & On line \\
\hline \multirow{2}{*}{$\begin{array}{r}\text { Burnup at discharge, } \mathrm{MWd} / \mathrm{t} \mathrm{HM} \\
\mathrm{TJ} / \mathrm{kg} \mathrm{HM}\end{array}$} & 7500 \\
\hline & 0.65 \\
\hline
\end{tabular}


Table A4. LMFBR Oxide Fuel Element Design Description

\begin{tabular}{lc}
\multicolumn{1}{c}{ Component } & Description \\
\hline & Assembly \\
Geometry & Hexagonal \\
Shroud material & $316 \mathrm{sS}$ \\
Assembly length & \\
Assembly gross mass, $\mathrm{kg}$ & 480 \\
Fuel rods per assembly & 271 \\
Enrichments per assembly & 1 \\
Heavy metal per assembly, $\mathrm{kg}$ & 148
\end{tabular}

Fuel Rods

Cladding material

316 SS

cladding outside diameter, mm

7.87

cladding inside diamter, mm

7.11

Fuel material

$(\mathrm{Pu}, \mathrm{U}) \mathrm{O}_{2}$

Fuel form

Pellet

Fuel diameter, mm

6.81

Fuel stack height, m

1.22

Fuel density, $\mathrm{Mg} / \mathrm{m}^{3}$

10.5

Fuel composition, wt \%

(z-1)

(z-2)

$(2-3)$

$(z-4)$

Uranium

75.2

74

73.7

67.9

Plutonium

12.8

14

14.3

20.1

Fissile material

Pu

Pu

$\mathrm{Pu}$

$\mathrm{Pu}$

Fissile material per total heavy metal, wt \%

14.5

15.9

16.3

22.9

Axial blanket length

Top, mm

356

Bottom, mm

356

Axial blanket material

$\mathrm{UO}_{2}$

Axial blanket form

Pellet

Axial blanket pellet diameter, mm

6.81

Axial blanket pellet density, $\mathrm{Mg} / \mathrm{m}^{3}$

10.4 
Table A4 (continued)

\begin{tabular}{ll}
\hline \multicolumn{1}{c}{ Component } & \multicolumn{1}{c}{ Description } \\
\hline End cap material & $316 \mathrm{SS}$ \\
Fuel-to-cladding thermal bond & He (slight positive pressure) \\
& \\
& Reactor Requirements \\
Initial core assemblies & 409 \\
Frequency of reloading & Annual \\
Assemblies per reload & 136 \\
Burnup at discharge, MWd/t HM & 75,000 \\
& 6.5 \\
\hline
\end{tabular}


Table A5 (continued)

\begin{tabular}{lll}
\hline Component & Description \\
\hline Fuel-to-cladding thermal bond & $\mathrm{Na}$ \\
& Reactor Requirements \\
Core assemblies & & 230 \\
\hline
\end{tabular}


Table A5. LMFBR Carbide Fuel Element Design Description

\begin{tabular}{|c|c|}
\hline Component & Description \\
\hline \multicolumn{2}{|c|}{ Assembly } \\
\hline Geometry & Hexagonal \\
\hline Shroud material & 316 SS \\
\hline Shroud mass, kg & 0.348 \\
\hline Fue1 rods per assembly & 91 \\
\hline Enrichments per assembly & 1 \\
\hline Heavy metal per assembly, $\mathrm{kg}$ & 102.1 \\
\hline \multicolumn{2}{|c|}{ Fue1 Rods } \\
\hline Cladding material & $316 \mathrm{SS}$ \\
\hline Cladding outside diameter, mm & 9.4 \\
\hline Fuel material & $(\mathrm{Pu}, \mathrm{U}) \mathrm{C}$ \\
\hline Fuel form & Pellet \\
\hline Fuel diameter, mm & 7.98 \\
\hline Fuel density, $\mathrm{Mg} / \mathrm{m}^{3}$ & 12.9 \\
\hline Fuel stack height, m & 0.914 \\
\hline Enrichment, \% & $\begin{array}{c}9.36(\mathrm{z}-1), 11.32(\mathrm{z}-2), \\
10.34 \text { (average) }\end{array}$ \\
\hline Axial blanket material & UC \\
\hline Axial blanket form & Pellet \\
\hline Axial blanket diameter, mm & 7.98 \\
\hline $\begin{array}{l}\text { Axial blanket pellet density, } \\
\mathrm{Mg} / \mathrm{m}^{3}\end{array}$ & 12.9 \\
\hline $\begin{array}{l}\text { Axial blanket stack heights } \\
\text { (top and bottom), m }\end{array}$ & 0.457 \\
\hline Reflector material & 316 SS \\
\hline \multicolumn{2}{|l|}{ Pellet fragment screen } \\
\hline Material & 316 SS \\
\hline Outside diameter, mm & 8.13 \\
\hline Thickness, mm & 0.08 \\
\hline
\end{tabular}


Table A6. LMFBR Metal Fuel Element Design Description

\begin{tabular}{|c|c|}
\hline Component & Description \\
\hline \multicolumn{2}{|l|}{ Assembly } \\
\hline Geometry & Hexagona1 \\
\hline Shroud material & 316 SS \\
\hline Shroud mass, kg & 0.348 \\
\hline Fue1 rods per assembly & 91 \\
\hline Enrichments per assembly & 1 \\
\hline Heavy metal per assembly, $\mathrm{kg}$ & 105.6 \\
\hline \multicolumn{2}{|l|}{ Fuel Rods } \\
\hline Cladding material & 316 SS \\
\hline Cladding outside dlameter, mm & 9.40 \\
\hline Fuel material & ${ }^{23}{ }^{3} \mathrm{U}-\mathrm{Th}$ alloy \\
\hline Fuel form & Metal slugs \\
\hline Fuel diameter, mm & 7.98 \\
\hline Fuel density, $\mathrm{Mg} / \mathrm{m}^{3}$ & 12.7 \\
\hline Fuel stack height, m & 0.914 \\
\hline Uranium content, $\%$ & 15 \\
\hline Axial blanket material & $\mathrm{U}$ metal \\
\hline Axial blanket form & Metal slug \\
\hline Axial blanket diameter, $\mathrm{mm}$ & 7.98 \\
\hline Axial blanket density, $\mathrm{Mg} / \mathrm{m}^{3}$ & 12.7 \\
\hline Axial blanket stack heights (top and bottom), $\mathrm{m}$ & 0.457 \\
\hline Reflector material, & 316 SS \\
\hline Fuel-to-cladding thermal bond & $\mathrm{Na}$ \\
\hline \multicolumn{2}{|l|}{ Reactor Requirements } \\
\hline Core assemblies & 230 \\
\hline
\end{tabular}


Table A7. GCFR Fuel Element Deslgn Description

\begin{tabular}{|c|c|}
\hline Component & Description \\
\hline \multicolumn{2}{|c|}{ Assembly } \\
\hline Geometry & $\begin{array}{l}\text { Hexagonal ( } 167.6 \mathrm{~mm} \\
\text { across flats) }\end{array}$ \\
\hline Shroud thickness, mm & 16.38 \\
\hline End fitting material & 316 SS \\
\hline Grid spacers & 10 \\
\hline Grid spacer materfal & 316 SS \\
\hline Assembly length, m & 3.45 \\
\hline Fuel rods per assembly & $\begin{array}{l}270(z-1), 232(z-3) \\
126 \text { (radial blanket) }\end{array}$ \\
\hline Enrichments per assembly & 1 \\
\hline Heavy metal per assembly, $\mathrm{kg}$ & 123.12 \\
\hline \multicolumn{2}{|c|}{ Fue1 Rods } \\
\hline Cladding material & 316 SS \\
\hline Cladding outside diameter, mm & $\begin{array}{l}7.16 \text { (core), } 12.80 \\
\text { (radial blanket) }\end{array}$ \\
\hline Cladding inside diameter, $\mathrm{mm}$ & $\begin{array}{r}6.20 \text { (core) }, 12.04 \\
\text { (radial blanket) }\end{array}$ \\
\hline Cladding length, $\mathrm{m}$ & 2.21 \\
\hline Fue1 material & $\begin{array}{l}(\mathrm{Pu}, \mathrm{U}) \mathrm{O}_{2} \text { (core), } \mathrm{ThO}_{2} \\
\text { (radial blanket) }\end{array}$ \\
\hline Fuel form & $\begin{array}{l}\text { Annular pellets (core), } \\
\text { Pellets (radial } \\
\text { blanket) }\end{array}$ \\
\hline Fuel diameter, $\mathrm{mm}$ & $\begin{array}{l}6.10 \times 1.27 \text { (core) } \\
6.15 \text { (radial } \\
\text { blanket) }\end{array}$ \\
\hline Fuel stack helght, m & 0.996 \\
\hline Fue1 density, $\mathrm{Mg} / \mathrm{m}^{3}$ & $\begin{array}{l}10.0 \text { (core), } 9.8 \\
\text { (radial blanket) }\end{array}$ \\
\hline Fissile material & $\mathrm{Pu}$ \\
\hline Axial blanket length, $\mathrm{m}$ & 0.450 (top and bottom) \\
\hline Plenum spring & Incone 1 \\
\hline
\end{tabular}


Table A7 (continued)

\begin{tabular}{ccc}
\hline Component & Description \\
\hline & Reactor Requirements \\
Burnup at discharge, MWd/t HM & 75,000 \\
& $\mathrm{TJ} / \mathrm{kg}$ & 6.5 \\
\hline
\end{tabular}


Table A8. HTGR Fue1 Element Design Description

\begin{tabular}{|c|c|}
\hline Component & Description \\
\hline \multicolumn{2}{|c|}{ Assembly } \\
\hline Geometry & Hexagonal \\
\hline Fue1 block & Graphite \\
\hline Assembly length, $\mathrm{mm}$ & 793 \\
\hline Assembly gross mass, $\mathrm{kg}$ & 117 \\
\hline Fuel block mass, kg & 109 \\
\hline Fuel rods per assembly & 1566 (132 stacks) \\
\hline Enrichments per assembly & 1 \\
\hline Heavy metal assembly (total), kg & 9.57 \\
\hline $\mathrm{U}$ & 0.742 \\
\hline Th & 8.83 \\
\hline \multicolumn{2}{|c|}{ Fuel Rods } \\
\hline SiC coating mass, $\mathrm{kg}$ & 1.1 \\
\hline Fuel material & ${ }^{235} \mathrm{U}, \mathrm{Th}$ \\
\hline Fuel form & Coated particles \\
\hline Fuel diameter, mm & 15.7 \\
\hline Fissile material & ${ }^{235} \mathrm{U}$ \\
\hline Enrichment, \% & 93 \\
\hline \multicolumn{2}{|c|}{ Reactor Requirements } \\
\hline Frequency of reloading & 4 years \\
\hline Burnup at discharge, $\mathrm{MWd} / \mathrm{t}$ & 85,000 \\
\hline $\mathrm{TJ} / \mathrm{kg}$ & 7.3 \\
\hline
\end{tabular}


. 
APPENDIX B - DETAILED RELATIVE COST ESTIMATION - INCREMENTAL FACTORS 
-

.

- 
Table B1. Detailed Cost Estimation Incremental Factors for Light-Water Reactors

\begin{tabular}{|c|c|c|c|c|c|c|c|c|c|c|c|c|c|c|c|c|c|c|}
\hline & & \multirow{3}{*}{$\begin{array}{l}\text { Category } \\
\text { Fraction }\end{array}$} & & & & & \multicolumn{4}{|c|}{$\left(\mathrm{Pu},{ }^{238} \mathrm{U}\right) \mathrm{O}_{2}$} & \multirow{2}{*}{\multicolumn{2}{|c|}{$(235 \mathrm{U}, \mathrm{Th}) \mathrm{O}_{2}$}} & \multirow{2}{*}{\multicolumn{2}{|c|}{$\left({ }^{23}{ }^{3} \mathrm{U}, \mathrm{Th}\right) \mathrm{O}_{2}$}} & \multirow{2}{*}{\multicolumn{2}{|c|}{$\begin{array}{l}(\mathrm{Pu}, \mathrm{Th}) \mathrm{O}_{2} \\
\text { Remote }\end{array}$}} & \multirow{2}{*}{\multicolumn{2}{|c|}{$\left(233 \mathrm{U},{ }^{238} \mathrm{U}\right) \mathrm{O}_{2}$}} \\
\hline & & & \multicolumn{2}{|c|}{$\begin{array}{l}\text { Element } \\
\text { Fraction }\end{array}$} & \multicolumn{2}{|c|}{$\left({ }^{235} \mathrm{U},{ }^{238} \mathrm{U}\right) \mathrm{O}_{2}$} & \multicolumn{2}{|c|}{ Glave Box } & \multicolumn{2}{|c|}{ Remote } & & & & & & & & \\
\hline & & & $\overline{\text { Contact }}$ & Other & $\operatorname{IM}^{\alpha}$ & Estımate & $\operatorname{IM}^{a}$ & Est imate & $1 M^{a}$ & Est Imate & $\operatorname{IM}^{a}$ & Est imate & $\mathrm{IM}^{\alpha}$ & Est Imate & $\mathrm{IM}^{2}$ & Estimate & $\mathrm{IM}^{\mu}$ & Estimate \\
\hline \multirow[t]{4}{*}{ A. } & Capital cost & 0.33 & & & & & & & & & & & & & & & & \\
\hline & Equipment & & 0.66 & 0.5 & 1 & 0.22 & 1.5 & 0.327 & 3 & 0.495 & 1.2 & 0.261 & 4 & 0.66 & 3 & 0.495 & 3 & 0.495 \\
\hline & Bullding & & 0.33 & 0.5 & 1 & $\underline{0.11}$ & 3 & 0.327 & 6 & 0.99 & 1 & $\underline{0.11}$ & 10 & 1.32 & 6 & 0.99 & 6 & 0.99 \\
\hline & Estimated factor & & & & & 0.33 & & 0.65 & & 1.49 & & $\begin{array}{c}0.37 \\
(0.40)^{b}\end{array}$ & & $\begin{array}{c}1.98 \\
(2.18)^{b}\end{array}$ & & 1.49 & & 1.49 \\
\hline \multirow[t]{6}{*}{ в. } & Hardware costs & 0.38 & & & & & & & & & & & & & & & & \\
\hline & $\begin{array}{l}\text { Cladding plus end } \\
\text { plugs }\end{array}$ & & 0.36 & 036 & 1 & 0.14 & 1 & 0.14 & 1 & 0.14 & 1 & 0.14 & 1 & 0.14 & 1 & 0.14 & & 0.14 \\
\hline & Rod internals & & Neg & & 1 & & 1 & & 1 & & 1 & & 1 & & 1 & & & \\
\hline & Assemb1y hardware & & 0.64 & 0.64 & 1 & 0.24 & 1 & 0.24 & 1 & 0.24 & 1 & 0.24 & 1 & 0.24 & 1 & 0.24 & & 0.24 \\
\hline & Est 1mated factor & & & & & 0.38 & & 0.38 & & 0.38 & & 0.38 & & 0.38 & & 0.38 & & 0.38 \\
\hline & & & & & & & & & & & & $(0.42)^{b}$ & & $(0.42)^{b}$ & & & & \\
\hline \multirow[t]{9}{*}{ c. } & Operatıng costs & 0.29 & & & & & & & & & & & & & & & & \\
\hline & Cladding preparation & & 0.19 & 0.19 & 1 & 0.06 & 1 & 0.055 & 1 & 0.055 & 1 & 0.055 & 1 & 0.055 & 1 & 0.055 & 1 & 0.055 \\
\hline & Fuel preparation & & 0.48 & 0.48 & 1 & 0.14 & 5 & 0.696 & 5 & 0.696 & 1.2 & 0.167 & 5 & 0.696 & 5 & 0.696 & 5 & 0.696 \\
\hline & Rod loading & & 0.02 & 0.02 & 1 & 0.01 & 2 & 0.012 & 2 & 0.012 & 1 & 0.006 & 2 & 0.012 & 2 & 0.012 & 2 & 0.012 \\
\hline & $\begin{array}{l}\text { Element assembly, } \\
\text { 1nspection, and } \\
\text { packaging }\end{array}$ & & 0.04 & 0.04 & 1 & 0.01 & 2 & 0.023 & 10 & 0.116 & 1 & 0.012 & 10 & 0.116 & 10 & 1.116 & 10 & 0.116 \\
\hline & Scrap recovery & & 0.14 & 0.14 & 1 & 0.04 & 4 & 0.162 & 4 & 0.162 & 2 & 0.081 & 4 & 0.162 & 6 & 0.244 & 2 & 0.081 \\
\hline & Waste treatment & & 0.14 & 0.14 & 1 & 0.04 & 10 & $\underline{0.406}$ & 10 & $\underline{0.406}$ & 2 & 0.081 & 10 & 0.406 & 10 & 0.406 & 10 & 0.406 \\
\hline & Estimated factor & & & & & 0.29 & & 1.35 & & 1.45 & & 0.40 & & 1.45 & & 1.53 & & 1.37 \\
\hline & & & & & & & & & & & & $(0.44)^{b}$ & & $(1.60)^{2}$ & & & & \\
\hline \multirow[t]{4}{*}{ D. } & $\begin{array}{l}\text { Fuel element design } \\
\text { factors (meta1 } \\
\text { clad rods only) }\end{array}$ & $\mathrm{NA}$ & & & & & & & & & & & & & & & & \\
\hline & Fuel density & & & & 1 & & & 1 & & 1 & & 1.1 & & 1.1 & & 1 & & 1 \\
\hline & Fuel diameter & & & & 1 & - & & $\underline{1}$ & & $\underline{1}$ & & 1 & & $\underline{1}$ & & $\underline{1}$ & & $\underline{1}$ \\
\hline & $\begin{array}{l}\text { Total estimated } \\
\text { factor }\end{array}$ & & & & & 1.0 & & 2.38 & & 3.32 & & 1.27 & & 4.19 & & 3.40 & & 3.24 \\
\hline
\end{tabular}

${ }^{a}$ Incremental multiplier estimate.

$b_{\text {Numbers in }}$ parentheses are IM values after corrections for fuel density and diameter 
Table B2. Detailed Cost Estimation Increments Factors for CANDU Reactors

\begin{tabular}{|c|c|c|c|c|c|c|c|c|c|c|c|c|}
\hline & & \multirow{2}{*}{$\begin{array}{l}\text { Category } \\
\text { Fraction }\end{array}$} & \multicolumn{2}{|c|}{$\begin{array}{r}\text { Element } \\
\text { Fraction }\end{array}$} & \multicolumn{2}{|c|}{$\left({ }^{235} \mathrm{U},{ }^{238} \mathrm{U}\right) \mathrm{O}_{2}$} & \multicolumn{2}{|c|}{$\begin{array}{c}\left(\mathrm{Pu},{ }^{238} \mathrm{U}\right) \mathrm{O}_{2} \\
\text { Remote }\end{array}$} & \multicolumn{2}{|c|}{$\left({ }^{23}{ }^{3} \mathrm{U}, \mathrm{Th}\right) \mathrm{O}_{2}$} & \multicolumn{2}{|c|}{$\begin{array}{l}(\mathrm{Pu}, \mathrm{Th}) \mathrm{O}_{2} \\
\text { Remote }\end{array}$} \\
\hline & & & Contact & Other & $\operatorname{mi}^{a}$ & Estimate & $\operatorname{IM}^{a}$ & Estimate & $\mathrm{IM}^{a}$ & Estimate & $\mathbf{I M}^{a}$ & Estimate \\
\hline \multirow[t]{4}{*}{ A. } & Capital cost & 0.33 & & & & & & & & & & \\
\hline & Equipment & & 0.66 & 0.5 & 1 & 0.218 & 3 & 0.495 & 7 & 0.660 & 3 & 0.495 \\
\hline & Bullding & & 0.33 & 0.5 & 1 & $\underline{0.109}$ & 6 & $\underline{0.990}$ & 8 & 1.32 & 6 & $\underline{0.990}$ \\
\hline & Estimated factor & & & & & 0.33 & & 1.49 & & 1.98 & & 1.49 \\
\hline \multirow[t]{6}{*}{ B. } & Hardware costs & 0.38 & & & & & & & & & & \\
\hline & $\begin{array}{l}\text { Cladding plus end } \\
\text { plugs }\end{array}$ & & 0.36 & 0.36 & 2 & 0.274 & 2 & 0.274 & 2 & 0.274 & 2 & 0.274 \\
\hline & Rod Internals & & Neg & & & & & & & & & \\
\hline & Assembly hardware & & 0.64 & 0.64 & 0.1 & $\underline{0.024}$ & 0.1 & $\underline{0.024}$ & 0.1 & $\underline{0.024}$ & 0.1 & $\underline{0.024}$ \\
\hline & Estimated factor & & & & & 0.30 & & 0.30 & & 0.30 & & 0.30 \\
\hline & & & & & & $(0.09)^{b}$ & & $(0.09)^{b}$ & & $(0.12)^{b}$ & & $(0.09)^{b}$ \\
\hline \multirow[t]{9}{*}{ c. } & Operating costs & 0.29 & & & & & & & & & & \\
\hline & Cladding preparation & & 0.19 & 0.19 & 2 & 0.110 & 2 & 0.110 & 2 & 0.110 & 2 & 0.110 \\
\hline & Fuel preparation & & 0.48 & 0.48 & 1 & 0.139 & 5 & 0.696 & 5 & 0.696 & 5 & 0.696 \\
\hline & Rod loading & & 0.02 & 0.02 & 1 & 0.006 & 1 & 0.006 & 2 & 0.006 & 2 & 0.006 \\
\hline & $\begin{array}{l}\text { Element assembly, } \\
\text { inspection, and } \\
\text { packaging }\end{array}$ & & 0.04 & 0.04 & 2 & 0.023 & 2 & 0.023 & 20 & 0.232 & 20 & 0.232 \\
\hline & Scrap recovery & & 0.14 & 0.14 & 1 & 0.041 & 4 & 0.162 & 4 & 0.162 & 6 & 0.244 \\
\hline & Waste treatment & & 0.14 & 0.14 & 1 & $\underline{0.041}$ & 10 & $\underline{0.406}$ & 10 & $\underline{0.406}$ & 10 & $\underline{0.406}$ \\
\hline & Estimated factor & & & & & 0.36 & & 1.40 & & 1.61 & & 1.78 \\
\hline & & & & & & $(0.11)^{b}$ & & $(0.43)^{b}$ & & $(0.55)^{b}$ & & $(0.55)^{b}$ \\
\hline \multirow[t]{4}{*}{ D. } & $\begin{array}{l}\text { Fuel element design } \\
\text { factors } b \text { (metal } \\
\text { clad rods only) }\end{array}$ & NA & & & & & & & & & & \\
\hline & Fue1 density & & & & & 1.0 & & $\sim 1$ & & 1.1 & & $n 1$ \\
\hline & Fuel diameter & & & & & $\underline{0.31}$ & & $\underline{0.31}$ & & $\underline{0.31}$ & & $\underline{0.31}$ \\
\hline & Total estimated $f$ & tor & & & & 0.53 & & 2.02 & & 2.65 & & 2.13 \\
\hline
\end{tabular}


Table B3. Detailed Cost Estimation Incremental Factors for Liquid-Metal-Cooled Fast Breeder Reactors

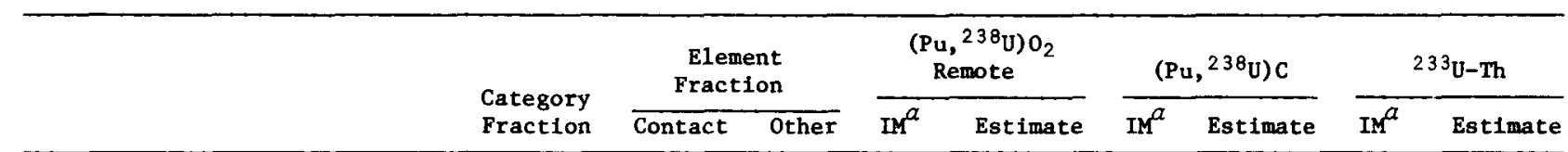

A. Capital cost

0.33

Equipment

Building

Estimated factor

\begin{tabular}{|c|c|c|c|c|c|c|c|}
\hline 0.66 & 0.5 & 6 & 0.990 & 10 & 1.650 & 10 & 1.650 \\
\hline 0.33 & 0.5 & 8 & 1.320 & 10 & 1.650 & 10 & $\underline{1.650}$ \\
\hline & & & $\begin{array}{c}2.31 \\
(3.19)^{b}\end{array}$ & & $\begin{array}{c}3.30 \\
(2.68)^{b}\end{array}$ & & $\begin{array}{c}3.30 \\
(2.73)^{b}\end{array}$ \\
\hline
\end{tabular}

B. Hardware costs

Clad plus end plugs

Rod internals

Assemb1y Hardware

Estimated factor

$\begin{array}{lllclclc}0.36 & 0.36 & 1 & 0.137 & 1 & 0.137 & 1 & 0.137 \\ \text { Neg } & & & 0.038 & & 0.076 & & 0.038 \\ 0.64 & 0.64 & 1 & \frac{0.243}{0.42} & 1 & \frac{0.243}{0.46} & 1 & \frac{0.243}{0.42} \\ & & & & & & \\ & & & (0.58)^{b} & & (0.37)^{b} & & (0.35)^{b}\end{array}$

c. Operating costs

Clad preparation

Fuel preparation

Rod loading

$\begin{array}{lccccccc}0.19 & 0.19 & 0.6 & 0.033 & 1 & 0.055 & 0.6 & 0.033 \\ 0.48 & 0.48 & 5 & 0.696 & 8 & 1.114 & 8 & 1.114 \\ 0.02 & 0.02 & 2 & 0.012 & 4 & 0.023 & 4 & 0.023 \\ & & & & & & & \\ 0.04 & 0.04 & 10 & 0.116 & 10 & 0.116 & 10 & 0.116 \\ 0.14 & 0.14 & 6 & 0.244 & 8 & 0.325 & 6 & 0.244 \\ 0.14 & 0.14 & 10 & \frac{0.406}{1.51} & 10 & \underline{0.406} & 10 & \underline{0.406} \\ & & & (2.08)^{b} & & (1.66)^{b} & & (1.61)^{b}\end{array}$

D. Fuel element design factors (metal clad rods only)

NA

Fuel density

Fuel diameter

$0.805 \quad 0.82$

Total estimated factor

1.38

1.01

1.01

Incremental modifier estimate.

$b$ Numbers in parentheses are IM values after correction for fuel density and diameter. 
Table B4. Detailed Cost Estimation Incremental Factors for Gas-Cooled Fast Breeder Reactors

\begin{tabular}{|c|c|c|c|c|c|c|c|c|c|c|}
\hline & & \multirow{2}{*}{$\begin{array}{l}\text { Category } \\
\text { Fraction }\end{array}$} & \multicolumn{2}{|c|}{$\begin{array}{l}\text { Element } \\
\text { Fraction }\end{array}$} & \multicolumn{2}{|c|}{$\left(\mathrm{Pu},{ }^{238} \mathrm{U}\right) \mathrm{O}_{2}$} & \multicolumn{2}{|c|}{$(233 \mathrm{U}, \mathrm{Th}) \mathrm{O}_{2}$} & \multicolumn{2}{|c|}{$(\mathrm{Pu}, \mathrm{Th}) \mathrm{O}_{2}$} \\
\hline & & & Contact & $\overline{\text { Other }}$ & $\operatorname{IM}^{a}$ & Estimate & $\mathrm{Im}^{a}$ & Estimate & $\operatorname{Im}^{a}$ & Estimate \\
\hline \multirow[t]{4}{*}{ A. } & Capital cost & 0.33 & & & & & & & & \\
\hline & Equipment & & 0.66 & 0.5 & 6 & 0.990 & 10 & 1.650 & 8 & 1.320 \\
\hline & Building & & 0.33 & 0.5 & 8 & $\underline{1.320}$ & 10 & $\underline{1.650}$ & 8 & $\underline{1.320}$ \\
\hline & Estimated factor & & & & & $\begin{array}{c}2.31 \\
(3.19)^{b}\end{array}$ & & $\begin{array}{l}3.3 \\
(5.01)^{b}\end{array}$ & & $\begin{array}{c}2.64 \\
(3.64)^{b}\end{array}$ \\
\hline \multirow[t]{5}{*}{ B. } & Hardware costs & 0.38 & & & & & & & & \\
\hline & Cladding plus end plugs & & 0.36 & 0.36 & 1 & 0.137 & 1 & 0.137 & 1 & 0.137 \\
\hline & Rod internals & & Neg & & & 0.15 & & 0.15 & & 0.15 \\
\hline & Assembly hardware & & 0.64 & 0.64 & 1.5 & $\underline{0.365}$ & 1.5 & $\underline{0.365}$ & 1.5 & $\underline{0.365}$ \\
\hline & Estimated factor & & & & & $\begin{array}{c}0.65 \\
(0.90)^{b}\end{array}$ & & $\begin{array}{c}0.65 \\
(0.99)^{b}\end{array}$ & & $\begin{array}{c}0.65 \\
(0.90)^{b}\end{array}$ \\
\hline \multirow[t]{8}{*}{ c. } & Operating costs & 0.29 & & & & & & & & $\cdot$ \\
\hline & Cladding preparation & & 0.19 & 0.19 & 1 & 0.055 & 1 & 0.055 & 1 & 0.055 \\
\hline & Fuel preparation & & 0.48 & 0.48 & 5 & 0.696 & 5 & 0.696 & 5 & 0.696 \\
\hline & Rod loading & & 0.02 & 0.02 & 4 & 0.023 & 4 & 0.023 & 4 & 0.023 \\
\hline & $\begin{array}{l}\text { Element assembly, } \\
\text { Inspection, and packaging }\end{array}$ & & 0.04 & 0.04 & 20 & 0.232 & 20 & 0.232 & 20 & 0.232 \\
\hline & Scrap recovery & & 0.14 & 0.14 & 6 & 0.244 & 8 & 0.325 & 8 & 0.325 \\
\hline & Waste treatment & & 0.14 & 0.14 & 10 & $\underline{0.406}$ & 10 & $\underline{0.406}$ & 10 & $\underline{0.406}$ \\
\hline & Estimated factor & & & & & $\begin{array}{c}1.66 \\
(2.29)^{b}\end{array}$ & & $\begin{array}{c}1.74 \\
(2.64)^{b}\end{array}$ & & $\begin{array}{c}1.74 \\
(2.40)^{b}\end{array}$ \\
\hline \multirow[t]{4}{*}{ D. } & $\begin{array}{l}\text { Fuel element design } \\
\text { factors (metal clad } \\
\text { rods only) }\end{array}$ & NA & & & & & & & & \\
\hline & Fuel density & & & & & 1 & & 1.1 & & 1 \\
\hline & Fuel diameter & & & & & $\underline{1.38}$ & & $\underline{1.38}$ & & $\underline{1.38}$ \\
\hline & Total estimated factor & & & & & 6.38 & & 8.64 & & 6.94 \\
\hline
\end{tabular}

ancremental modifier estimate.

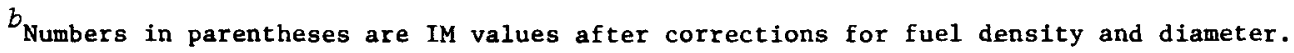


Table B5. Detailed Cost Estimation Incremental Factors for High-Temperature Gas-Cooled Reactors ${ }^{a}$

\begin{tabular}{|c|c|c|c|c|c|c|c|c|c|c|c|c|}
\hline & & \multirow{2}{*}{$\begin{array}{l}\text { Category } \\
\text { Fraction }\end{array}$} & \multicolumn{2}{|c|}{$\begin{array}{r}\text { Element } \\
\text { Fraction }\end{array}$} & \multicolumn{2}{|c|}{$\left(235 \mathrm{UO}_{2}-\mathrm{ThO}_{2}\right)$} & \multicolumn{2}{|c|}{$\left({ }^{233} \mathrm{UCO}-\mathrm{ThO}_{2}\right)$} & \multicolumn{2}{|c|}{$\left({ }^{235} \mathrm{U},{ }^{238} \mathrm{U}\right) \mathrm{O}_{2}$} & \multicolumn{2}{|c|}{$\left(\mathrm{PuO}_{2}-\mathrm{ThO}_{2}\right)$} \\
\hline & & & Contact & Other & $\mathrm{IM}^{b}$ & Estimate & $\mathrm{IM}^{b}$ & Estimate & $\mathrm{IM}^{b}$ & Estimate & $\mathrm{IM}^{3}$ & Estimate \\
\hline \multirow[t]{4}{*}{ A. } & Capital cost & 0.26 & & & & & & & & & & \\
\hline & Equipment & & 0.66 & 0.5 & 1 & 0.17 & 3.5 & 0.45 & 0.9 & 0.15 & 3.5 & 0.45 \\
\hline & Building & & 0.33 & 0.5 & 1 & $\underline{0.09}$ & 6 & $\underline{0.78}$ & 0.9 & $\underline{0.08}$ & 6 & $\underline{0.78}$ \\
\hline & Estimated factor & & & & & 0.26 & & 1.23 & & 0.23 & & 1.23 \\
\hline \multirow[t]{5}{*}{ B. } & Hardware costs & 0.42 & & & & & & & & & & \\
\hline & Miscellaneous components & & 0.09 & & 1 & 0.038 & 1 & 0.038 & 1 & 0.038 & 1 & 0.038 \\
\hline & Fertile particles & & 0.18 & & 1 & 0.076 & 1 & 0.076 & 0 & & 1 & 0.076 \\
\hline & Graphite blocks and plugs & & 0.73 & & 1 & $\underline{0.307}$ & 1 & $\underline{0.307}$ & 1 & $\underline{0.307}$ & 1 & $\underline{0.307}$ \\
\hline & Estimated factor & & & & & 0.42 & & 0.42 & & 0.35 & & 0.42 \\
\hline \multirow[t]{3}{*}{ c. } & Operating Cost & 0.32 & & & & & & & & & & \\
\hline & Lump sum estimate & & & & 1 & $\underline{0.32}$ & 3 & $\underline{0.96}$ & 1 & $\underline{0.32}$ & 3 & $\underline{0.96}$ \\
\hline & Total estimated factor & & & & & 1.00 & & 2.61 & & 0.90 & & 2.61 \\
\hline
\end{tabular}

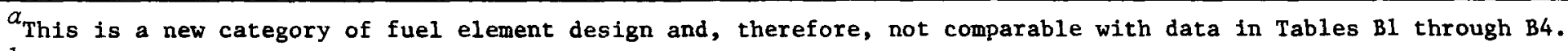

$b_{\text {Incremental modifier estimate. }}$ 
0 
ORNL/TM-5961

Distribution

Category UC-77

INTERNAL DISTRIBUTION

1-2. Central Research Library

3. Document Reference Section

4-5. Laboratory Records Department

6. Laboratory Records, R. C.

7. ORNL Patent Section

8. P. Angelini

9. W. J. Armento

10. D. E. Bartine

11. R. L. Beatty

12. E. J. Bomar, Jr.

13. T. J. Burns

14. A. J. Caputo

15. W. L. Carter

16. R. G. Donnel1y

17. R. W. Glass

18. P. A. Haas

19. F. E. Harrington

20. R. E. Helms

21-23. M. R. Hill

24. F. J. Homan

25. D. R. Johnson

26-30. R. R. Judkins

31-33. P. R. Kasten

34. K. J. Notz

35. W. J. Lackey

36. E. H. Lee
37. E. J . Long, Jr.

38. A. L. Lotts

39. R. E. Norman

40. J. E. Mack

41. A. D. MAtchell

42-51. A. R. O1sen

52. R. L. Pearson

53. J. P. Renier

54. T. F. Scanlan

55. J. E. Selle

56. I. Spiewak

57. D. P. Stinton

58. V. J. Tennery

59. D. B. Trauger

60. S. M. Tiegs

61. J. S. Vavruska

62. H. J. Wallace

63. R. P. Wichner

64. B. A. Worley

65. D. F. Williams

66. R. W. Balluffi (Consultant)

67. A. L. Bement, Jr, (Consultant)

68. W. R. Hibbard, Jr. (Consultant)

69. E. H. Kottcamp, Jr. (Consultant)

70. M. J. Mayfleld (Consultant)

71. J. T. Stringer (Consultant)

EXTERNAL DISTRIBUTION

72. HANFORD ENGINEERING DEVELOPMENT LABORATORY, P.0. BOX 1970, Richland, WA 99352

M. C.J. Carlson

73. PACIFIC NORTHWEST LABORATORY, P.0. Box 999, Richland, WA 99352

S. Goldsmith

74-75. DOE DIVISION OF NUCLEAR POWER DEVELOPMENT, Washington, DC 20545

A. J. Pressesky, Acting Director

W. W. Ballard, Nuclear Fuel Cycle Program Branch 
76. DOE OFFICE OF NUCLEAR ENERGY PROGRAM, Washington, DC 20545

R. L. Ferguson, Director

77. DOE SAN FRANCISCO OPERATIONS OFFICE, 1333 Broadway, Wells Fargo Building, Oakland, CA 94612

Manager

78-79. DOE OAK RIDGE OPERATIONS OFFICE, P.O. BOX E, Oak Ridge, TN 37830

Assistant Manager, Energy Research and Development

S. W. Ahrends

80-255. DOE TECHNICAL INFORMATION CENTER, P.0. Box 62, Oak Ridge, TN 37830

For distribution as shown in TID-4500 Distribution Category, UC-77 (Gas-Cooled Reactor Technology) 